\begin{tabular}{llll} 
ZAPISKI HISTORYCZNE & Zeszyt 2 \\
\hline
\end{tabular}

http://dx.doi.org/10.15762/ZH.2016.63

\author{
KRZYSZTOF KWIATKOWSKI \\ (Nicolaus Copernicus University of Toruń)
}

\title{
(WILD)HAUS IN BEZŁAWKI (BAYSELAUKEN, BÄSLACK) - REMARKS ON THE CONSTRUCTION OF FORTIFICATIONS OF THE TEUTONIC ORDER IN LATE MEDIEVAL PRUSSIA*
}

Key words: Late Middle Ages, late medieval Prussia, Warmia (Ermland), castles, construction of fortifications, the military affairs in the Late Middle Ages, conflicts

In recent times there has been an increase in interest by researchers on the field of castellology that took place on the area of late medieval Prussia. The variety of subjects discussed range from analytical studies of distinct sets of buildings both based on specific sources and a homogenous methodology ${ }^{1}$ to the interdisciplinary research of specific strongholds. ${ }^{2}$ Such variety increases the frequency of archeological research, each one employing as it does, the most up-to-date measuring equipment and architectural analysis. Excavations are carried out both in large and major sites of the Late Middle Ages and within smaller ones where their military and strongholdlike functions seem to trump their economic, administrative and symbolic ones. In the research groups which are formed for such research deliberations naturally go beyond the subject matters being under archeological

* This article is an English version of the article which appeared in "Zapiski Historyczne", vol. 81, 2016. Translation was part of the task "The publication of 'Zapiski Historyczne' in the English language version, Vol. 81, 2016, books (zeszyt 1-4)" financed as part of the agreement 698/P-DUN/2016 with the resources of the Ministry of Science and Higher Education devoted to the popularization of science.

${ }^{1}$ See also among others: Sławomir Jóźwiak, Janusz Trupinda, Krzyżackie zamki komturskie $w$ Prusach. Topografia i układ przestrzenny na podstawie średniowiecznych źródeł pisanych, Toruń 2012; Sławomir Jóźwiak, Zamki krzyżackie w średniowiecznych źródłach pisanych), [in:] Zamki, pałace, dwory i ich mieszkańcy w regionie kujawsko-pomorskim, ed. Waldemar RozYnkowski, Małgorzata Strzelecka, Michał Targowski (Region kujawsko-pomorski w przeszłości, vol. 1. 1), Toruń 2013, pp. 13-31.

${ }^{2}$ Among a number of publications such research can be seen in: Wielki Refektarz na Zamku Średnim w Malborku. Dzieje - wystrój - konserwacja, ed Janusz TRuPInDA, Malbork 2010; Zamek w Grudziądzu w świetle badań archeologiczno-architektonicznych. Studia i materiały, ed Marcin WIEWIóRA, Toruń 2012; Zamek biskupów chetmińskich w Wąbrzeźnie w świetle badań archeologicznoarchitektonicznych. Studia i materialy, ed Marcin Wiewióra, Toruń 2014; Kazimierz PospiesznY, Domus Malbork. Zamek krzyżacki w typie regularnym, Toruń 2014; Maria Sp£AwsKa-KorczaK, Zamek krzyżacki w Świeciu. Próba rekonstrukcji zamku wysokiego w średniowieczu, Toruń 2014. 
and architectural reviews which is an unevoidable from the point of view of research and context analysis.

In 2013, a monograph was published on a late medieval settlement in Bezławki (Bayselauken, in German: "Bälsack") which was the result of a collaborative research effort carried out over a number of years in two separate locations (one is a castle which since the $16^{\text {th }}$ century has functioned as a church and another situated in the grounds of the cemetery in the centre of the present (and probably late medieval) village). ${ }^{3}$ The monograph discussed views on various military aspects of the castle. As a whole, this work can be judged positively and even serve as an example for other publications which undertake architectural and archeological research of such sites and archeological undertakings around them however it must be pointed out that some of the presented ideas and concepts in $\mathrm{it}^{4}$ may arouse some controversy.

These controversies come under six basic areas. The first one deals directly with the military functions of Bezławki stronghold. The second one includes the weakness of the castle as an element of the defense system. The third concerns morphological typology issues of edifices called "wildhaus" and seeing where Bezławki stronghold falls within this. The fourth refers to the question of the administrative functions the place might have fulfilled. The fifth broadens the scope of the research onto the problem of the connections between a building stronghold and the establishment of settlements. The sixth tries to ascertain the reasoning behind the erection of the castle in Bezławki. In this article due to space constrictions only the first three issues which can be classified precisely as military problems will be dealt with. The remaining three aspects will be addressed in a later separate study.

\section{THE MILITARY FUNCTIONS OF BEZŁAWKI (WILD)HAUS}

Bezławki stronghold which is still well preserved can be assumed to be a fortress due to its so called castle house and bailey surrounded by a curtain wall. $19^{\text {th }}$ century researchers designated it as belonging to a separate group of small fortified points erected by those who held power in Prussia such as the Teutonic Order, bishops and Prussian church chapters, in the more highly developed eastern

${ }^{3}$ Bezławki - ocalić od zniszczenia. Wyniki prac interdyscyplinarnych prowadzonych wlatach 2008-2011, ed. Arkadiusz Koperkiewicz (Gdańskie Studia Archeologiczne. Seria Monografie, Nr 3), Gdańsk 2013.

${ }^{4}$ Some aspects of how the castle in Bezławki functioned at the turn of the $14^{\text {th }}$ and $15^{\text {th }}$ centuries were also presented a little earlier by the head of the research group Arkadiusz Koperkiewicz and by Wojciech Brillowski in their joint article published in 2012, see Wojciech BRILLOWski, Arkadiusz Koperkiewicz, Archaeological and Art History Research in Bezławki. Analysis of the Form and Function of Small Castle Architecture in the Eastern Part of The Teutonic Order's Lands, [in:] Castella Maris Baltici X. Finland 24-29.8.2009. Raseborg, Olavinlinna and Häme Castles, ed. Kari Uotila, Terhi Mikкola, Anna-Maria Vilkuna (Archaeologia Medii Aevi Finlandiae, vol. 18), Saarijärven 2012, pp. 33-43 (a number of architectural and functional issues presented in this article are repeated by Wojciech Brillowski in his text included in a monograph from 2013, see idem, Analiza funkcjonalna założenia obronnego w Bezławkach, [in:] Bezławki - ocalić od zniszczenia, pp. 119-135. 
and south eastern parts of Prussia as well as on the western edges of the so called "Great Wilderness" ("Grosse Wildnis"). ${ }^{5}$ In Prussian historiography from the $19^{\text {th }}$ and $20^{\text {th }}$ century such castles are referred to as "Wildhäuser" or "Wildburgen," a term which derives from local Middle High German in which such objects were called "wilthusz" or "wildhaus" which means "wilderness house." At this point the fact should be stressed that there were never any known instances of the Bezławki stronghold being referred to by the term "wildhaus." A few written records from the Teutonic Order mention the word "hus" (in English "house" $)$, which was

${ }^{5}$ Carl Beckherrn, Das Ordenshaus Bäslack, Altpreußische Monatsschrift (further cit. AM), Bd. 21: 1884, pp. 637-638 (=Sitzungsberichte der Altertumsgesellschaft Prussia zu Königsberg in Pr., H. 10: 1883-1884 [1885], pp. 75-85); Die Bau- und Kunstdenkmäler der Provinz Ostpreußen (further cit. BKDPOP), bearb. v. Adolf BoETTischer, H. 2: Natangen, Königsberg 1898, p. 15; Emil J. GutTzeit, Bäslack, [in:] Ost- und Westpreussen, hrsg. v. Erich WeIse (Handbuch der historischen Stätten), Stuttgart 1966 ( $1^{\text {st }}$ edition) (the $2^{\text {nd }}$ edition: 1981), p. 14.

${ }^{6}$ Among number/numerous of mentions and more or less detailed discussions see: Theodor HiRsch, [in:] Scriptores rerum Prussicarum (further cit. SRP), Bd. 2, Leipzig 1863, p. 497, footnote 300; Carl Steinbrecht, Die Baukunst des Deutschen Ritterordens in Preußen, Bd. 4: Die Ordensburgen der Hochmeisterzeit in Preußen. Bau-Aufnahmen und baugeschichtliche Würdigung der noch vorhandenen Burgen und bedeutenderen Burg-Reste des Ordens in Preußen aus der Zeit von 1310 bis zum Ende der Ordens-Herrschaft, Berlin 1920, p. 72; Georg MATERN, Burg und Amt Rößel. Ein Beitrag zur Burgenkunde des Deutschordenslandes, Königsberg 1925, pp. 4, 5, 7, 8; Karl Heinz Clasen, Die mittelalterliche Kunst im Gebiete des Deutschordensstaates Preußen, Bd. I: Die Burgbauten, Königsberg i. Pr. 1927, pp. 131-132, 140-142; Fritz GrIGAT, Die Besiedlung des Mauerseegebietes im Rahmen der Kolonisation Ostpreußens, Heimatforschung aus Ostpreußens Mauerseegebiet, Tl. 4, Königsberg Pr. [1932], pp. 30, 31, 32, 33, 36; Hans Koeppen, Die Verhandlungen um den Abbruch der Burg Rajgród und deren Zerstörung, [in:] Studien zur Geschichte des Preussenlandes. Festschrift für Kurt Forstreuter zu seinem 70. Geburtstag, hrsg. v. Ernst BAHR (Ostdeutsche Beiträge aus dem Göttinger Arbeitskreis, Bd. 9), Würzburg 1958, pp. 47-57, here pp. 56-57; Friedrich Benninghoven, Die Burgen als Grundpfeiler des spätmittelalterlichen Wehrwesens im preußisch-livländischen Deutschordenstaat, [in:] Die Burgen im deutschen Sprachraum. Ihre rechts- und verfassungsgeschichtliche Bedeutung, hrsg. v. Hans PATZE (Vorträge und Forschungen, Bd. 19, Tl. 1), Sigmaringen 1976, pp. 565-601, here pp. 570, 575; Sven Ekdahl, The Strategic Organization of the Commanderies of the Teutonic Order in Prussia and Livonia, [in:] La Commanderie, institution des ordres militaires dans l'Occident médiéval, sous la dir. Anthony Luttrell, Léon Pressouyre, Archéologie et d'historie de l’art, vol. 14, Paris 2002, pp. 219-242, here p. 232; Christofer Herrmann, Deutschordensburgen in der „Grossen Wildnis”, [in:] Castella Maris Baltici, vol. 6, ed. Albinas Kuncevičıus (Archaeologiae Medii Aevi Finlandiae, vol. 7), Vilnius 2004, pp. 97-103, pp. 100-102; idem, Burgen im Ordensland. Deutschordens- und Bischofsburgen in Ost- und Westpreußen. Ein Reisehandbuch, Würzburg 2006, p. 36. In general literature dealing with the subject of fortifications/strongholds in wider, European context see: August v. CoHAusen, Die Befestigungwesen der Vorzeit und des Mittelalters, hrsg. v. Max JäHns, Wiesbaden 1898, p. 236 (who quite rightly writes about "Wildhöfe" - "the wilderness courts").

${ }^{7}$ See Geheimes Staatsarchiv des Preußischen Kulturbesitzes Berlin-Dahlem (further cit. GStA PK), XX. HA, OF 1, p. 51 (edition: Ausrüstung der Burgen in der Wildnis bei Insterburg durch den obersten Marschall [Conrad von Wallenrod] (further cit. ABW) (Anhang (a): Die littauischen Wegeberichte (Beilage I: Die Chronik Wigands von Marburg. Originalfragmente, lateinische Übersetzung und sonstige Überreste), hrsg. v. Theodor Hirsch, [in:] SRP, Bd. 2, p. 708).

${ }^{8}$ Johanns von Posilge, Officials von Pomesanien Chronik des Landes Preussen (von 1360 an, forgesetzt bis 1419) (further cit. OPChLP), hrsg. v. Ernst STREHLKe, [in:] SRP, Bd. 3, Leipzig 1866, pp. 13-388 
a common term known to the order and applied to more or less complex castle buildings. ${ }^{9}$ The Bezławki defence edifice was also described as a "hof" (in English "courtyard" ${ }^{10}$ ). What is more, the fact that there are a paucity of medieval sources on Bezławki implies describing it as a wildhause is open to conjecture. Both its location, ${ }^{11}$ and other functioning aspects suggest a close link to some fortified buildings described in the $14^{\text {th }}$ and $15^{\text {th }}$ centuries as "wilderness houses."

In reference to the morphology of Bezławki castle, Wojciech Wółkowski in an article discussing its architectural characteristics stresses the significance of its relatively big courtyard (size 42,3 $\times 51,8 \mathrm{~m}$ ) which in his opinion acted as "a safe camp area for Teutonic Order campaign participants." 12 Its second partly military function was in his opinion, the protection of the rural community (and probably forest dwellers) in the event of an invasion, ${ }^{13}$ and from the later half of the $14^{\text {th }}$ century it became connected with the military enterprises of Lithuanian dukes and military leaders. Among those people, there were potential military candidates who could be used to augment those securing the castle's fortifications. ${ }^{14}$ Such a practice was required due to the small number of permanent castle inhabitants available to provide basic military protection. There are no surviving records which would show the number of people residing in Bezławki castle, apart from some estimates made regarding the number of court servants during Duke Bolesław Švitrigaila's residency (around 40 from the autumn of 1402 to the beginning of 1404). ${ }^{15} \mathrm{~A}$ single reference dating from 1412 about four crossbows with

(edition on page 79-388), here page 259 (for 1402 ); Das grosse Ämterbuch des Deutschen Ordens (further cit. GÄB), hrsg. v. Walther ZIESEMER, Danzig 1921 (repr.: Wiesbaden 1968), 155.25 (1412).

${ }^{9}$ Marian Dygo, Domus und Castrum - zur Deutung der Deutschordensburgen in Preußen im Lichte der schriftlichen Quellen, [in:] Echte Wehrhaftigkeit oder martialische Wirkung. Zur praktischen Funktion und zum Symbolcharakter von Wehrelementen profaner und sakraler Bauten im Deutschordensland Preußen und im Ostseeraum, hrsg. v. Gerhard EImer, Ernst GierLich (Kunsthistorische Arbeiten der Kulturstiftung der deutschen Vertriebenen, Bd. 3), Köln 2000, pp. 53-58; Sławomir Jóźwiak, Janusz Trupinda, Krzyżackie zamki komturskie w Prusach, pp. 35-36, 66, 96-98. In the light of S. Jóźwiak's detailed study, one should assume (as did Mieczysław HAFTKA, Zamki krzyżackie $w$ Polsce. Szkice z dziejów, Malbork-Płock 1999, p. 37), that in the case of the Bezławki stronghold the word "hus" referred not to fortified building as a whole but only to the so called castle house and not to the neighbouring bailey surrounded by an enclosure/enciente.

${ }^{10}$ GStA PK, XX. HA, Perg.-Urk., Schiebl. XXVI, No. 238 (no date [years 1396-1404]).

${ }^{11}$ Theauthor of the aformentioned Chronicle of the Prussian country (Cronike des landes von Pruszin), points out that "a house" (German: "hus") was located "in front of the wilderness" ("vor die wiltnisse"), see OPChLP, p. 259.

${ }^{12}$ W. WóŁкоwsкi, Architectura zamku w Bezławkach, [in:] Bezławki - ocalić od zniszczenia, pp. 110, 111.

${ }^{13}$ Ibid., p. 111. The theory of the refuge function of Bezławki castle is not new and was recently revisited by Tomasz ToRBus, Zamki krzyżackie/Deutschordensburgen, trans. Łukasz BiENIAsz, Wrocław 2010, p. 31. Earlier also M. HaftKa (op.cit., p. 36) related the settlement in Rastenburg region (presently Polish Kętrzyn) to the "increased necessity of defending this part of the country."

${ }^{14}$ W. WóŁKOWsKI, op.cit., p. 111.

${ }^{15}$ Seweryn SzczepańsKi, Bezławki i okolice w kontekście osadniczym plemiennej Barcji oraz kętrzyńskiego okręgu prokuratorskiego w średniowieczu, [in:] Bezławki - ocalić od zniszczenia, pp. 28-30 
windlass ${ }^{16}$ does not exactly provide a detailed account of the weaponry available but confirms the fact that the people securing the castle were poorly equipped in hand ranged weapons. However if you compare it with another military description of arms stored in nine "Wildhäuser" in 1384 under Königsberg's Command$\mathrm{er}^{17}$ then it turns out that the state of weaponry in Bezglawki should not be viewed as critical (as could have been the case after the war period of 1409-1411) ${ }^{18}$ but should be seen as a norm for these kind of fortified buildings, ${ }^{19}$ bearing in mind the fact that this mention possibly shows a snapshot of a changing and frequently altering state of crossbows available. On the basis of the above data one can assume that most of the small fortified buildings, which were located in the western edges of the Great Wilderness usually did not have more than a dozen inhabitants.

Detailed architectural studies including the use of laser scanning ${ }^{20}$ and thermo-visual measurements, ${ }^{21}$ conducted in 2011 and 2012 by a research group under the leadership of Arkadiusz Koperkiewicz established the existence of a number of openings in the walls of the castle house (presently the church). It turned out that they were in total four walls on all four levels and additionally on both top walls. It is highly probable that they were also in both surfaces of the roof covering the attic area. Most of them were used as shooting holes. According to Wojciech Brillowski's analysis there were 67 (or 73 holes if the ones on the roof are included) on all five levels of the building, 23 or 26 of which were in the north-west wall, 10 in the south-west top wall, 23 or 26 in the south-east on the side of the courtyard and 11 in the north-east top wall. ${ }^{22}$ To provide an effective and a number of days defence of a castle (approximately of the size: $25,6 \times 11,8 \times 25,8 \times 11,8 \mathrm{~m})^{23}$ one would need from 50 to about 100 armed men. ${ }^{24}$ To fully man a 140 -metre-lengthwall (not taking into the account the two exterior flanking towers and three open

(sources mentioned by the researcher suggest the presence of at least 30 armed men who would assist the Duke and at least nine courtmen and servants).

${ }^{16}$ GAB, 155.24-25; see also M. HAFtKA, op.cit., p. 39; S. SzCZEPAŃsKi, op.cit., p. 30.

${ }^{17}$ ABW, pp. 708-709. In most of the wildhauses there were from two to eight different crossbows.

${ }^{18}$ As suggested by M. HAFTKA, op.cit., p. 39; and followed by S. SzCZEPAŃsKI, op.cit., p. 30; and W. BRILlowsKI, Analiza funkcjonalna założenia obronnego w Bezławkach, p. 130; see also W. BRILLowski, A. Koperkiewicz, Archaeological and Art History Research in Bezławki, p. 42.

${ }^{19}$ An example of "wildhaus" (although with some interpretational mistakes in the source materials) was already provided by Carl Beckherrn with the example of Tammow as a reference point for Bezławki castle, see idem, Das Ordenshaus Bäslack, AM, Bd. 21: 1884, p. 647.

${ }^{20}$ Karolina Hejbudzka, Andrzej Dumalski, Paweł Łata, Dokumentacja 3D obiektow zabytkowych metoda skanowania laserowego, [in:] Bezławki - ocalić od zniszczenia, pp. 220-233.

${ }^{21}$ Wiesław Nawrocki, Badanie termowizyjne i geofizyczne kościoła w Bezławkach, [in:] Bezław$k i$ - ocalić od zniszczenia, p. 275.

${ }^{22}$ W. BRILlowski, Analiza funkcjonalna założenia obronnego w Bezławkach, pp. 124-127.

${ }^{23}$ Ibid., p. 124; sea also W. Brillowski, A. Koperkiewicz, Archaeological and Art History Research in Bezławki, p. 38.

${ }^{24}$ In the 1880 s C. Beckerrn theoretically estimated the maximum number of people residing in the castle house to be 120 and of the whole stronghold to 400 military men, however with regards 
towers) there were about 70 or more armed men needed. This would mean that a military crew of several-hundred would not be able to resist even a medium size force of invaders (50-100 or 100-200 men) if these aforementioned invaders had some basic equipment at their disposal enabling them to force the castle gate and enter the castle house. Effective defence against numerous invaders unlike a small gang of wilderness marauders (so-called "strutere") ${ }^{25}$ was not possible without taking on extra armed men - the inhabitants of surrounding villages (both Freien or various representatives of villagers or "wilderness" people, forest dwellers) and organised rescue force or forces despatched to rescue from another castle (or other castles).

Referring to the results of archaeological research, Wojciech Wółkowski writes about the unsuitability of quite a large castle courtyard for a long-lasting defence of the fortification. ${ }^{26}$ In his opinion, this is shown by the existence of an open inward outline in both open towers used along with the curtain wall (from the south west, south east and north east sides) as well as both corner bedchamber towers. His arguments are not fully convincing as open towers were defined in the Middle Low and Middle High German used in the Late Middle Ages Prussia as "wîkhûs", "wîchûs", or "wîchhûs," ${ }^{27}$ and were in no way intended for short periods of fortifications defence. ${ }^{28}$ In addition to other defence elements (considering a tower system) they were to provide protection of a town during a siege no matter how long it would last. According to Wółkowski and Brillowski, the towers and curtain walls were neither very high (up to 5 metres) nor thick (around 1,5 m) ${ }^{29}$ however they were of significant defensive importance connected with the fact that the courtyard was located on the highest section of the hill and partly over the steepest slopes so there was maybe no real need to dig a moat around the castle. ${ }^{30}$ It should be stressed that the archaeological research was confined to one open and one bedchamber tower only. The partial archaeological research undertaken did not conclusively prove that the curtain wall came with a crenellation or a wooden

to the defence systems of the $19^{\text {th }}$ century theoretical and practical military aspects, see idem, Das Ordenshaus Bäslack, p. 647.

${ }^{25}$ In reference to such military activities see also Krzysztof KwIATKоwsкi, Kulturelle Bedingungen der militärischen Aktivität im Spätmittelalter: der Fall des Preußen(landes) unter der Herrschaft des Deutschen Ordens (I), Ordines Militares. Colloquia Torunensia Historica. Yearbook for the Study of Military Orders, vol. 18: 2013, pp. 156-167.

${ }^{26}$ W. Wó£KOWsKI, op.cit., p. 111.

${ }^{27}$ Mittelhochdeutsches Handwörterbuch (further cit. MHDHWB), hrsg. v. Matthias LeXer, Bd. 3 (Vf-Z. Nachträge), Leizpig 1878, szp. 818; Mittelniederdeutsches Wörterbuch (further cit. MNDWB), hrsg. v. Karl SCHILler, August LüBBen, Bd. 5 (U-Z), Bremen 1880, p. 713.

${ }^{28}$ Which is mentioned by the researcher himself, see also. W. Wó£KowsKI, op.cit., p. 110.

${ }^{29}$ Ibid., p. 110, footnote 10; W. BRILlowski, Analiza funkcjonalna założenia obronnego w Bezławkach, p. 122.

${ }^{30}$ W. BRILlowsKi, Analiza funkcjonalna założenia obronnego w Bezławkach, p. 122; Arkadiusz Koperkiewicz, Zamek w Bezławkach w świetle badan archeologicznych, [in:] Bezławki - ocalić od zniszczenia, p. 72 . 
external porch (sidewalk?) and the towers topped with a wooden platform. However, it is highly probable it did as otherwise the whole idea of building a "high" wall of a few metres, considerably above the average man's height thus unabling military activities from behind the wall without creating on the top of it suitable posts for the defenders, would not have made much sense. ${ }^{31}$ As defending these relatively uncomplicated positions surrounding the courtyard, did not require highly coordinated communication, villagers or people of the forest, when needed, could man them. In this way there was considerable overlap between both the defensive and refugial functions of the castle. As to whether the courtyard was at least partly built (to reduce the refugial capacity of the castle) is a moot point. ${ }^{32}$

In the light of the above one has to completely agree with Wółkowski's hypothesis on refugial and defensive functions of Bezławki castle as well as with Brillowski's view about the refuge the castle provided to both settlers from the dominion of the Teutonic Order and possibly of the Bishops of Ermland. Brillowski assumes the usable area of the castle to be over 1000 square metres (to which one can add the area of a 2000 square metre courtyard) and that it could have provided refuge to a few hundred people at any one time. ${ }^{33}$

However, there have been objections raised to both Wółkowski's and belief that Bezławki castle was a "fortified camp area" as well as Koperkiewicz's view of Bezławki as "a meeting and starting point for military campaigns." ${ }^{44}$ Koperkiewicz claims that the courtyard surrounded by a curtain wall "was a resting place for a garrison during field campaign" 35 although it is not very clear what is meant by an anachronical for a late medieval period term of "garrison." By "garrison" he most probably is referring to a military situation in which Bezławki castle would be augmented by a bigger than the number of its residents, military crew [sent by a neighbouring military group operating in the environs to provide assistance. Such a state of affairs more than likely occurred in the so called Lithuanian War in the $14^{\text {th }}$ century, ${ }^{36}$ however no surviving records remain to confirm the veracity of this assertion. Such a military action was described as an "occupation" ("besaczunge") but the term "occupation" would imply that the fortified objects had been just seized and conquered. ${ }^{37}$ It would have been very unusual if there was a gather-

${ }^{31}$ W. BRILLOwSKI, Analiza funkcjonalna założenia obronnego w Bezławkach, pp. 122-123.

${ }^{32}$ A positive opinion on this matter was expressed by W. BRILlowski, Analiza funkcjonalna założenia obronnego w Bezławkach, p. 130 (following the idea of: M. НAFTKA, op.cit., p. 37) along with W. Wó£Kowski, op.cit., p. 113 (who uses the partly verified example of Leunenburg (Polish Sątoczno) - which however is not parallel to Bezławki, see below pp. 28-29).

${ }^{33}$ W. BRILLowsKI, Analiza funkcjonalna założenia obronnego w Bezławkach, p. 131; also: W. BRILLowski, A. Koperkiewicz, Archaeological and Art History Research in Bezławki, p. 39.

${ }^{34}$ A. Koperkiewicz, Zamek w Bezławkach, p. 71.

${ }^{35}$ Ibid.

${ }^{36}$ Krzysztof Kwiatкowsкi, Wojska zakonu niemieckiego w Prusach 1230-1525, korporacja, jej pruskie władztwo, zbrojni, kultura wojny i aktywność militarna (Dzieje Zakonu Niemieckiego, vol. 3), Toruń 2016, pp. 228, 282.

${ }^{37}$ GStA PK, XX. HA, Ordensbriefarchiv (further cit. OBA) 1120, 1128, 1454. 
ing of a hundred strong group of people or even an average size army in Bezławki castle who in turn would have set off to attack Lithuanian or Black Ruthenian land. There are a few reasons why one should be sceptical about the courtyard being viewed as a place of camp area theory. First of all, big military campaigns were organised by those at the top of the Teutonic Order (Gebietiger) and medium size ones by brothers in charge of the castles, subject to the commands of their superiors, who held an office of reeve (Vogt), procurator (Pfleger), woodruff (Waldmeister) and piscine masters' (Fischmeister). Only in terms of significant military actions can the potential "strategic" significance and advantages of Bezławki castle ascribed to by Koperkiewicz be justified. ${ }^{38}$ To date, there is no certainty that this castle was run by a member of the Teutonic Order or that he filled any of the aforementioned posts. Some researchers see Bezławki castle as an example of a so called "Kämmerer's castle", ${ }^{39}$ with no proof however that such an official existed there. No instances of Kämmerer's organising, following the monastic dignitaries instructions, less significant (small) military campaigns/Reisen are known of, yet their help and activities undertaken in organising contingents for bigger campaigns and participation in them is well proven ${ }^{40}$ however again no mention exists of Kämmerer undertaking such enterprises of their own accord. On an everyday basis they dealt with administrative duties in regard to the indigenous populace. ${ }^{41}$ Even if there had been instances of individual military campaigns undertaken by some

${ }^{38}$ A. Koperkiewicz, Zamek $w$ Bezławkach, p. 45. The Gdańsk archeologist (is not the only one referred to in the aformentioned Bezławki monograph) who seems to overuse the term "strategic." He applies it almost every time he talks about "military campaigns" or "army." Thus it seems that for him both terms: "military" and "strategic" are synonymous. However there is a significant semantic difference between the two: with the first term being the more general to describe all the aspects, dimensions and people involved in military activities and the second applied only to some aspects or forms connected with the general military context of a particular military campaign, characterized by its praxeological (including organizational) complexity. In the contemporary written records of military history, there is common agreement that in Latin cultural circles of the Middle Ages, the category of "strategy" did not exist as conceptual or analytical instrumentarium and thus could not be used as an analytical tool. See also Beatrice Heuser, Den Krieg denken. Die Entwicklung der Strategie seit der Antike, Paderborn-München-Wien-Zürich 2010, pp. 17-20 (compare the originally German version with its partially changed English version: The evolution of strategy: thinking war from antiquity to the present, Cambridge 2010, pp. 3-5). That is why using it in contemporary scientific analyses (with some exceptions) is anachronistic and leads to some inadequate ideas about past military human activities being propagated or wrong interpretations being applied. I have focused on the problem in my most recently published book, see. K. KWIATKOWsкI, Wojska zakonu niemieckiego w Prusach 1230-1525, pp. 221-222 (excursus 21).

${ }^{39}$ See below.

${ }^{40}$ Krzysztof Kwiatкошsкi, Zakon niemiecki jako „corporation militaris”, part. I: Korporacja $i$ krag przynależących do niej. Kulturowe i społeczne podstawy działalności militarnej zakonu w Prusach (do poczatku XV wieku) (Dzieje Zakonu Niemieckiego, vol. 1), Toruń 2012, pp. 262-263, 357-358; idem, Wojska zakonu niemieckiego w Prusach 1230-1525, pp. 114, 163, 193, 239, 288, 293.

${ }^{41}$ Idem, Zakon niemiecki jako „corporation militaris”, pp. 352-357; idem, Wojska zakonu niemieckiego w Prusach 1230-1525, pp. 114, 119 (in the first book is collected the literature related to the office Kämmerer). 
people belonging to the Orders' Corporation (Dienere) to Lithuanian or Black Ruthenian Land, with the gathering of armed forces taking place in Bezławki castle, neither the term "strategic" nor such military significance could not be applied to them as they were would be more alike the uncontrolled sometimes strutters' actions. Bezławki castle fulfilled some military functions of significance such as a providing defence and offering a place of refuge but to describe it as being of "strategic" importance is a step too far.

The hypothesis involving the alleged "strategic" role of Bezławki castle is based on one single source. It is referred to the fragment of "The Chronicle of the Prussian Land" (Cronike des landes von Pruszin) of the Pomesanian judicial vicar which is mentioned numerous times in various studies of the subject. ${ }^{42}$ This allegedly confirms, also according to the authors of Gdańsk monograph of 2013, the arrival of the Grand Commander Wilhelm von Helfenstein accompanied by the Duke of Lithuania, Bolesław Švitrigaila in the summer of 1402 to Bezławki on their return trip from the campaign against Lithuania and the installation of a this Lithuanian ruler in the castle. The link between the castle and this campaign is stressed and the castle is viewed as a stopping off point for the army. ${ }^{43}$ However all the above is based on the misinterpretation of two narrations from the aforementioned chronicle. ${ }^{44}$ Due to space limitations a detailed analysis of these two text fragments is left out.

One cannot deny the more significant military role the Bezławki castle played during Bolesław Švitrigaila's stay there between the autumn of 1402 and the beginning of 1404. From the preserved sources it is evident that during next big campaign against Lithuania at the beginning of 1403 (after the one mentioned above from 1402), an ultimate gathering of the Teutonic Order's army led by Grand Marshal Werner von Tettingen was to have taken place in Letzenburg (Polish: Giżycko) around the $14^{\text {th }}$ January. ${ }^{45}$ Numerous "guests"/crusaders mentioned by the Pome-

${ }^{42}$ Johannes VoIGt, Geschichte Preussens von den ältesten Zeiten bis zum Untergange der Herrschaft des Deutschen Ordens, Bd. 6: Die Zeit des Hochmeisters Konrad von Jungingen von 1393 bis 1407. Verfassung des Ordens und des Landes, Königsberg 1834, p. 225; recently in a group monograph on Bezławki: S. SzczePAŃsKI, op.cit., pp. 27-28; W. WóŁKOWSKI, op.cit., p. 111, footnote 11; W. BRILlowski, Analiza funkcjonalna założenia obronnego w Bezławkach, p. 130; see also: A. KoPerkiewicz, Zamek w Bezławkach, p. 71; W. Brillowski, A. Koperkiewicz, Archaeologicaland Art History Research in Bezławki, p. 40.

${ }^{43}$ About 20 years ago M. Haftka wrote that, "the castle played an important role in the Teutonic Order's crusade against Vilnius in the summer of 1402" and that "the Grand Commander Wilhelm von Helfenstein stopped with his army in Bezławki on the way back from a failed campaign," see: M. HAFTKA, op.cit., p. 37.

${ }^{44}$ OPChLP, pp. 259-260.

${ }^{45}$ Księga komturstwa gdańskiego (further cit. KKG), ed. Karola CiesielsKa, Irena JAnoszBiskupowa, Fontes TNT, vol. 70, Warszawa-Poznań-Torun 1985, p. 236. On this day as expected there was a contingent from the Gdańsk Commandery, which we know was supposed to gather around the $6^{\text {th }}$ January, 1403, see GStA PK, XX. HA, OBA 689. There was a separate gathering of the Königsberg (under the command of the Grand Marshal), Balga, Brandenburg and Christburg contingents (with the last gathering in Christburg (Polish: Dzierzgoń), see GStA PK, XX. HA, OBA 689. 
sanian judicial vicar arrived probably in Letzenburg with the Königsberg's contingent and Grand Marshal. Originally, the campaign was supposed to head for Grodno but finally, in Letzenburg, the decision was made to head for Merkin (Old Polish: Merecz, Lithuanian: Merkine).$^{46}$ Bearing in mind the fact that towards the end of 1402 an attack was planned for Black Ruthenia, it can be assumed, following later narration from Jan Długosz's chronicle, that in this military action, Bolesław Švitrigaila ${ }^{47}$ with his military attendants also took part and that his supporters could have been in tow. However at that time, Bezławki castle was neither a staging post nor a camp area for the army. It was the place where the Lithuanian duke and his court stayed and the place where they set off on their military campaign, most probably heading for Letzenburg, on the way to Lithuania or Ruthenia. The Grand Commander's army route from Letzenburg towards Merkin coincided probably with the one described in a collection of itineraries, that in the $19^{\text {th }}$ century was called "Littauische Wegeberichte."48

Bezławki was not involved in military actions in the subsequent months of 1403 when the Teutonic Order's army operated in the region of Ragnit (Russian: Neman) and contingents called up for the purposes of landweren camped in Sambia or near Friedland (Old Polish: Frydląd, Russian: Pravdinsk). ${ }^{49}$ In subsequent years the military undertakings of the Prussian branch of the Teutonic Order centred on Samogitia ${ }^{50}$ (if the two Gotland campaigns of 1404 are disregarded ${ }^{51}$ ), away from Bezławki stronghold. In the light of this, the statement made by Seweryn Szczepański, where he says: "after the Lithuanian duke departure, Bezławki castle still acted as a guarding post on the important campaign routes towards Samogitia

${ }^{46}$ OPChLP, p. 264.

${ }^{47}$ His participation in the winter campaign of 1403 is mentioned by Jan Długosz (see Joannis Dlugossii Annales seu Cronicae incliti Regni Poloniae, lib. X (1370-1405), ed. Stanisław GawĘDA [et alii], Varsaviae 1985, p. 253), and the coverage is repeated by Maciej z Miechowa (see Maciej z Miechowa, Chronica Polonorum, Cracoviae 1521 (facsimile publishing: Kraków 1986), cap. XLII, p. cclxxvi); the information from both chronicles are followed by Tomasz Stolarczyк, Na karuzeli życia czyli walki Świdrygiełly o tron litewski 1392-1430 [http://warsztathistoryka.uni.lodz.pl/podstrony/ sredniowiecze.html, accessed 23.03.2016], pp. 13-14.

${ }^{48}$ Wegeberichte, W. 60, p. 691.

${ }^{49}$ OPChLP, pp. 265-266, 266; Franciscani Thorunensis Annales Prussici (941-1410) (further cit. FTAP), hrsg. v. Ernst Strehlke, SRP, Bd. III, Leipzig 1866, pp. 13-388 (edition on pp. 57-316), p. 266; Das Elbinger Kriegsbuch (1383-1409). Rechnungen für städtische Aufgebote, bearb. v. Dieter HecKmann u. Mitarbeit v. Krzysztof Kwiatkowski, Veröffentlichungen aus den Archiven Preußischer Kulturbesitz, Bd. 68, Köln-Weimar-Wien 2013 (edition on pp. 89-202), p. 166; KKG, p. 237.

${ }^{50}$ J. Voigt, Geschichte Preussens, Bd. 6, pp. 323-327, 329-335; Robert Krumbholtz, Samaiten und der Deutsche Orden bis zum Frieden am Melno-See, AM, Bd. 27: 1890, pp. 48-57; recently as well: Marek Radoch, Walki Zakonu Krzyżackiego o Żmudź od połowy XIII wieku do 1411 roku, Olsztyn 2011, pp. 206-213.

${ }^{51}$ J. VoIGT, Geschichte Preussens, Bd.6, pp. 260-265; and more analytically: Friedrich BenningHoven, Die Gotlandfeldzüge des Deutschen Ordens 1398-1408, Zeitschrift für Ostforschung, Jg. 13: 1964, H. 3, pp. 456-472. 
and Lithuania," sounds amis. ${ }^{52}$ Who and against whom was the castle supposed to protect in this configuration of directions? Its guarding role as mentioned later, might and must have been renewed also after 1410 because conflicts with the Grand Duchy of Lithuania did not cease until 1422; however not on the military route "in the direction of Samogitia and Lithuania" but on the crossing on one of the side routes leading from the east and south east, from the Great Wilderness and Black Ruthenia to the fast developing from the 1450s the south-east part of the Ermland Bishopry land. ${ }^{53}$

The above analysis makes it clear that the authors of the monograph on Bezławki in the Late Middle Ages overrated its military significance, assigning too many military functions it did not fulfill. Koperkiewicz's opinion seems to be symptomatic as he sees the courtyard as buildings located along the curtain wall ${ }^{54}$ and as a vast square for "garrison" use in times of military action. In the case of Bezławki, where the courtyard is no more than ca $2000 \mathrm{~m}^{2}$, one choice or the other has to be made. Koperkiewicz refuses to give credence to Bezławki's both functioning as a "camp" or a supply base at the same time but to validate his hypothesis further research needs to be done to locate some sections of courtyard's wooden outhouses (like a stable, smithy or wood carving workshop) As the first function suggested by Koperkiewicz was neglected in the above analysis a more favourable eye should be cast on suggested by him possibility of having located some courtyard's wooden outhouses in some parts of the courtyard (like a stable, smithy or wood carving works hop).

\section{DEFENCE SYSTEM ELEMENT?}

Another point I would like to discuss as a side issue after reading the articles from the monograph on Bezławki is the question of the "systemic" character of fortifications erected by the Teutonic Order in the Late Middle Ages Prussia and the question of possible role Bezławki castle might have played in such a system. The fact of the matter is that the authors refer to and at the same time silently accept the opinions present in the older literature ${ }^{55}$ according to which, fortified

${ }^{52}$ S. SzCZEPAŃsKi, op.cit., p. 30.

${ }^{53}$ The issues which constitute the sixth aformentioned subject matter of Bezławki stronghold's functioning will be discussed in a separate article.

${ }^{54}$ A. Koperkiewicz, Zamek w Bezławkach, p. 71.

${ }^{55}$ See also. F. Grigat, op.cit., p 30; Ireneusz SŁAwIŃski, Strategia i funkcje zamku średniowiecznego oraz rozwój jego elementów obronnych na przykładzie zamków Polski pótnocnej-głównie terytorium dawnego państwa krzyżackiego oraz pogranicza polsko-krzyżackiego, PZK Biuletin no. 8, Warszawa 1968, pp. 50-51 (there are conclusions drawn on the existence of signal communications between two sets of castles in Kulmerland and Powiśle); F. Benninghoven, Die Burgen als Grundpfeiler des spätmittelalterlichen Wehrwesens, p. 570 (He writes about two "chains of castles" ("Burgenketten") in the southern edges of the Great Wilderness and the lower Nemen River); p. 600 (here mentioned "a castle system" within the country ("Burgensystem"), alleged to have countrywide range thus fulfilling defensive function for the country; Marian Arszyński, Die Burgen im Deutschordensland PreuBenals Quelle zur Erforschung der Geschichte des Deutschen Ordens und seines Staates, [in:] Werkstatt 
points built by the Order (or more precisely under his supervision) constituted some kind of "defence system" (or "defence systems"). There is a more or less direct approval of such hypothesis. Seweryn Szczepański points out that Bezławki castle in "the post-Grunwald era" "did not play any significant role in the Teutonic Order's state' defence system" [accentuation by K.K.]. ${ }^{56}$ Arkadiusz Koperkiewicz writes about Bezławki castle as "a watchtower in a line of st ro n holds, protecting the state' eastern borders [i.e. of Prussia country: accentuation by K.K.] (Pisz, Ełk, Okartowo, Szestno, Ryn, Giżycko, Kętrzyn, Węgorzewo and Barciany)." ${ }^{\prime 7}$ Wojciech Wółkowski when referring to Marian Arszyński’s description of a group of strongholds functioning at the end of $14^{\text {th }}$ century $y^{58}$ in the region of Ragnit assumes that "a similar concept building was realised [...] at the border of Galindian Wilderness" and that "a part of this great spaceinstallation [accentuation by K.K.] were castles built towards the end of the $14^{\text {th }}$ century in Barciany and Ryn which were originally designed as commander's castles and a number of smaller ones in Garbno, Kętrzyn, Bezławki and Szestno." 59 Finally, Wojciech Brillowski as he states himself when introducing the issue, discusses "the reasons behind the failure of the system [accentuation by K.K] of which Bezławki castle was a part." 00

Doubts should be raised when interpreting the existence of "a system" as incontrovertible proof in the available literature to validate this assertion does not exist. One has the impression that for many scientists, looking at modern smallscale maps and the positioning of certain objects on them may give the the impression of "defence lines" or "fortified groupings," which in turn is enough to give

des Historikers der mittelalterlichen Ritterorden. Quellenkundliche Probleme und Forschungsmethoden, hrsg. v. Zenon H. NowaK (Ordines Militares - Colloquia Torunensia Historica, [vol.] 4), Toruń 1987, p. 101; idem, Die Deutschordensburg als Wehrbau und ihre Rolle im Wehrsystem des Ordenstaates Preußen, [in:] Das Kriegswesen der Ritterorden im Mittelalter, hrsg. v. Zenon H. NowaK (Ordines Militares - Colloquia Torunensia Historica, [Bd.] 6), Toruń 1991, pp. 114-116 (the author is sceptical about the "system" hypothesis); see also: M. HAFTKA, op.cit., pp. 16, 36, 103, 279 (in reference to various fortified points); see also Sylvain Gouguenheim, Krzyżacy, trans. Małgorzata Dalla Bella, Sławomir JóźwIAK, ed. Janusz TrupindA, Sławomir Jóźwiak, Malbork 2012 (oryg.: Les chevaliers teutoniques, Paris 2007), p. 143 (talks about the $13^{\text {th }}$ century fortified buildings in the eastern Powiśle region functioning as "systems").

${ }^{56}$ S. SZCZEPAŃsKi, op.cit., p. 30.

${ }^{57}$ A. Koperkiewicz, Zamek w Bezławkach, p. 45. The Gdańsk archeologist repeats M. Haftka’s opinion (op.cit., p. 36).

${ }^{58}$ The author is mistaken about the existence of the system at the end of the $15^{\text {th }}$ century and repeats it twice in his work, see W. WóŁKOWsKI, op.cit., p. 114. It is repeated after M. Arszyński’s publication (Budownictwo warowne zakonu krzyżackiego, p. 180); in which there was an actual misprint made because from the context it is quite clear that the Torun researcher was talking about the end of the $14^{\text {th }}$ century, see also: idem, Die Deutschordensburg als Wehrbau, p. 115 (here expressis verbis is mentioned when referring to the 14th century); idem, Architektura warowna zakonu krzyzackiego w Prusach, p. 22.

${ }^{59}$ W. WóŁKOWsKI, op.cit., p. 114.

${ }^{60}$ W. Brillowski, Analiza funkcjonalna założenia obronnego w Bezławkach, p. 121; see also W. Brillowski, A. Koperkiewicz, Archaeological and Art History Research in Bezławki, p. 34. 
credence to the system hypothesis. The line which can be depicted from maps based on fortified buildings does not necessary mean that these points were created or erected with a defence system in mind. ${ }^{61}$

For a greater understanding of the issue a definition of "a defence system" needs to be explored. In studies on fortifications, the term "system" understood as a collection of fortified buildings, in which at least one set or a few elements (i.e. buildings) joint together as one in order to realise one or more paramount functions to the ones fulfilled separately. Such a term as well as "a fortification system" is applied in relation to single fortified buildings in order to give a general picture of specific defence practice applied which were based on usage specific defence elements and practices. ${ }^{62}$ Historians who deal specifically with military affairs, use the term "defence system" when talking about sets of fortified buildings thus leading to a general understanding of the word "system" as "a complex thing." The application of "a system" like quality means that the individual structures had some prior function, which could not be realised by each one separately. So "defence system" is always a functional category and not a physical (a real physical object). Following this reasoning it is difficult to accept Wółkowski’s use of this term in regards to a number of remote castles which according to him would have created "a greatspace installation." The first of such fortifications were ring fortresses which were

${ }^{61}$ The "system" hypothesis is not exclusively used as an interpretational tool in Prussian historiography as the same categories are applied for example in Lithuanian written records in reference to fortified points erected in the lower and middle Nemen River by the Lithuanian rulers from the second quarter of the $14^{\text {th }}$ century and by some researchers even to earlier buildings, see i.a. Alvydas NiKžENTAITIS, Rašytiniai šaltiniai apie Lietuvos piliu gynybinę sistema XIII a. pabaigoje - XIV a. pradžioje [Written record about the Lithuanian fortified castles system from the end of the $13^{\text {th }}$ and the begining of the $14^{\text {th }}$ centuries], Lietuvos TSR Mokslų Akademijos darbai, serija A, visuomenès mokslai, vol. 3 (96): 1986, pp. 51-62; idem, Litauen unter den Großfürsten Gedimin (1316-1341) und Olgerd (1345-1377), [in:] Die „Blüte” der Staaten des östlichen Europa im 14. Jahrhundert, hrsg. v. Mark Löwener (Deutsches Historisches Institut Warschau. Quellen und Studien, Bd. 14), Wiesbaden 2004, p. 71; Gintautas Zabiela, Defensive Systems of Wooden Castles in Lithuania in the $13^{\text {th }}-14^{\text {th }}$ Centuries, [in:] Castella Maris Baltici, vol. 3-4, ed. Kaur AlttoA, Knut Drake, Kazimierz PoSPIEsZny, Kari Uotila (Archaeologia Medii Aevi Finlandiae, vol. 5), Turku-Tartu-Malbork 2001, pp. 199-205. The existence of defence systems on the territory of the Kingdom of Poland was pointed out by Tadeusz PoKLEWski-KozieŁe, The royal castles and defensive towns on trading routes through Poland to the Baltic Sea in the $14^{\text {th }}-15^{\text {th }}$ century. A contribution to the history of country defence system planning, [in:] Castella Maris Baltici, vol. 6, pp. 147-152 (Polish translation: Zamki królewskie i miasta obronne na drogach handlowych prowadzących przez Polskę nad Morze Bałtyckie w XIV i XV wieku. Przyczynek do znajomości systemu planowania obrony kraju, [in:] idem, Studia o zamkach średniowiecznych, oprac. Jerzy MaIK, Maria ŻemigaŁA (Collectio archaeologica, historica et ethnologica, vol. 5), Warszawa 2012, pp. 99-108). On small and uncomplicated late medieval defence systems on the territories of the Roman empire, see August von CoHAUSEn, op.cit., pp. 191-192

${ }^{62}$ See also. Janusz Bogdanowski, Podstawy systematyki dzieł obronnych, [in:] Mały słownik terminologiczny dawnej architektury obronnej w Polsce (further cit. MSTDAO), ed. Janusz BogDANOwski, Zygmunt Holcer, Marian Kornecki, Andrzej Swaryczewski, Wrocław 1974 (ed. 1; ed. 2: Kraków 1986), pp. 11-13 (quote from the $2^{\text {nd }}$ editon); MSTDAO, pp. 78-79; Stefan Fuglewicz, Ilustrowana historia fortyfikacji, Warszawa 1991, pp. 3a-b. 
recognized since 1870s as consisting of a number of elements (such as forts and citadels) all interconnected to constitute a whole single defence construction. ${ }^{63}$ "Defence system" does not imply single defence building but is created by at least one set of buildings or fortified buildings whose complexity requires the occupation of a vast area. Fortifications are human creations so they were erected with certain intentions in mind and over the course of time these initial intentions were adapted to fit in with changing circumstances thus a certain set of fortified buildings can be applied to as a "system" only when they were erected with an intention, motif and plan of its creation or built in various circumstances (with various intentions, motifs and plans) and in the course of time, they were re-adapted to constitute such a system i.e. fulfill the paramount function. The latter can be expressed as "postdefined systems" as opposed to "the primary" or "predefined systems." In both cases the deciding factor were human intentions and plans at the time and not the retrospective interpretations of present day researchers. A defence system does not occur as a coincidence or an incident but is a conscious creation of a man, the builder. At the same time it is not a creation of imagination or interpretation of the later observers or analysts; it cannot be backdated. In reference to late medieval Prussia the whole hypothesis of "defence system" or "defence systems" so far seems to have been based on the historiographical, interpretational sphere.

The problem had already been dealt with by Marian Arszyński who pointed to the functioning of such a castle arrangement located on the Neman River (mainly around the Ragnit region) stressing the fact that there is no proof of its intended and projected character. The recognition of the intentionality of the Teutonic Order in creating a system on the Neman River (as far as the Nevezžis estuary) at the end of the $14^{\text {th }}$ century, are contained in sources however he fails to provide any. ${ }^{64}$ Arszyński bases his claims on the topographic location of the buildings, their positioning in relation to the settlement and various aspects of organisation of their construction (among others how they were centrally financed) and how they were later supplied. ${ }^{65} \mathrm{He}$ saw another system in relation to castles erected "around Ełk" (German: Lyck). ${ }^{66} \mathrm{He}$ stressed the fact that many groups of castles would acquire a system character only ex post ${ }^{67}$ In the light of the definition presented they would both be "postdefined systems" rather than "predefined."

Arszyński's ideas show that there are a lack of written sources confirming the intentions and plans behind the creation of fortified systems. As research stands at present there is a lack of evidence to prove the intentionality of those who built the edifices to create systems so the "system hypothesis" is based on indirect proof or only premises, a sine qua non condition, the homogeneous chronology of the

${ }^{63}$ See also. MSTDAO, p. 39; J. Bogdanowski, op.cit., p. 11; S. Fuglewicz, op.cit., p. 1a.

${ }^{64}$ M. ArsZYŃSKI, op.cit., p. 180 (there was a misprint as the $15^{\text {th }}$ century was being talked about).

${ }^{65}$ Ibid., p. $180-181$.

${ }^{66}$ Ibid., p. 181 (The author was not precise enough to mention which fortified points around Ełk he meant so one cannnot refer to it.)

${ }^{67}$ Ibid. 
building, its potential development and the length of time it functioned applicable to all the fortified elements/buildings. It is necessary to state that in many cases, establishing the exact date of the erection of the building is simply impossible or unambiguous and usually, it is chronological data that is used to draw conclusions about only possible existence of a "postdefined system."

A more powerful indicator is location. Geographical position can provide an abundance of information, especially when looked at from natural and anthropogenic enviroment' points of view even though these are insufficient unless some similarities are traced. Strong conclusions can be arrived at after an analysis of the location of the fortified points as it can show the natural and anthropogenic conditions prevailing, enabling the determination of one or more major functions; basic features of a system arrangement to be made. The fact that one potential, major function can be determined is fundamental but does not provide direct proof. The fact that a group of fortified buildings could comprise a system of fortifications does not mean that such a system existed. Fortified points cannot exist as defence systems without active or passive human usage which in military terms means that they are manned. However even unmanned fortifications defined as "barriers," 68 still fulfil functions even though these functions need human participation in providing protection thus slowing down the activities of the aggressor. If the location of a group of fortified structures implies their potential defence system function its actual existence as such is decided upon by the way they were exploited by people or groups of people cooperating together. A group of fortified points with the same chronology and suitable location will not create a defence system in of themselves if not supported by people undergoing certain practices, such as the usage of the prepared infrastructure to cooperate within different neighbouring buildings. The larger the number of paramount functions the higher the level of its "system."

In regard to Bezławki castle, the indirect arguments presented so far, pointing to the possibility of its functioning as a part of a set of elements constituting a defence system are opposed to opinions expressed in the aforementioned monograph from 2013. The places mentioned by Koperkiewicz are: Pisz (German: Johannisburg), Ełk (Lyck), Okartowo (German: Eckersberg), Szestno (German: Seehesten), Ryn (German: Rhein), Giżycko (Letzenburg), Kętrzyn (German: Rastenburg), Węgorzewo (German: Angerburg) and Barciany (Bartenburg) however their favourable location does not prove anything. One can even go further and state they do not create any sort of an arrangement. In case of Eckersberg, there is very little known about the chronology of its functioning (apart from some notices

${ }^{68}$ Aleksander Alexandrowicz-Witold, Rozwój historyczny fortyfikacji w zarysie), Toruń 1924 ( $1^{\text {st }}$ edition); Oświęcim 2010 ( $2^{\text {nd }}$ edition), pp. 54-63 (quotation from $2^{\text {nd }}$ edition); Karol KLECZKE, Władysław Wyczyński, Fortyfikacja stała, Warszawa 1937 ( $1^{\text {st }}$ edition); Oświęcim 2014 (2 ${ }^{\text {nd }}$ edition), pp. 20-26 (quotation from the $2^{\text {nd }}$ edition); Ryszard [H.] BocheneK, Od muru chińskiego do linii Maginota. 50 wieków historii fortyfikacji, Warszawa 1964, pp. 100-104; Marian Rogalski, Maciej ZABORowski, Fortyfikacja wczoraj i dziś, Warszawa 1978, pp. 52-55; Stefan FugLEwICz, op.cit., pp. 20a, 21a. 
from 1361 and 1377/1379) ${ }^{69}$ and the castle in Lyck was probably erected in $1398,{ }^{70}$ so it seems that the group of fortified points that was mentioned by Koperkiewicz could not have existed as a fortified arrangement at the same time. Even if the buildings did function simultaneously it still does not prove that they constituted a set of elements joined together as one functional unity. With the present-day knowledge of certain fortresses, their infrastructure and organisation there is no possibility such a vast defence system, consisting of a set of a few elements, covering a latitudinal area $65 \mathrm{~km}$ south and $70 \mathrm{~km}$ parallel to this could have existed. It might as well have extended as far north as $80 \mathrm{~km}$ thus reaching the castle in Labiau. It is important to be aware of the fact that the researchers who "brought to life" such defence systems of late medieval Prussia did not define their major military functions (apart from some vague mentions of their usage in the defence against Lithuanian invasions) but what needs to be stressed once again is that these were different from the functions they would realise separately.

I am of the opinion that instead of omnipresent tendencies prevalent in the literature regarding the creation of vast, multifunctional defence systems one should concentrate on analysing local and small sets of fortified points separately. Indeed the question arises whether they should be called "systems" at all. There were some steps taken in the Bezławki monograph by Brillowski to do this when he rendered some general remarks on the possible signal communication between Bezławki castle and city of Rastenburg (Polish: Kętrzyn). ${ }^{71}$ This researcher does not define, however how the communication would have been organised and most importantly who would have received the signals in Rastenburg. Was communication possible between Bezławki castle and the Teutonic Order's castle in Rastenburg or maybe just with the tower of St. George parochial church (acting, as it were, beside the church as an element of the city's fortifications) $?^{72}$ The answers to these questions are crucial as without them we cannot even generally define the ways the

${ }^{69}$ Die Chronik Wigands von Marburg. Original fragmente, lateinische Übersetzung und sonstige Überreste (further cit. Wigand), hrsg. v. Theodor Hirsch, [in:] SRP, Bd. 2, pp. 429-662 (edition on p. 453-662), here cap. 52, p. 527; cap. 106, p. 596; OPChLP, p. 80; see also: BKDPOP, H. 6: Masuren, Königsberg 1896, p. 34.

${ }^{70}$ OPChLP, p. 220-221; see also: BKDPOP, H. 6, p. 63 (by wrongly attributing the initiaton of the edifice's construction to the year 1390.

${ }^{71}$ W. BRILLOwski, Analiza funkcjonalna założenia obronnego w Bezławkach, p. 131.

${ }^{72}$ BKDPOP, H. 2, p. 154; Carl BECKHERRN, Rastenburg historisch-topographisch dargestellt, Rastenburg 1880, p. 21; Andrzej Rzempoøuch, Przewodnik po zabytkach sztuki dawnych Prus Wschodnich, Olsztyn 1993, p. 56; Ch. Herrmann, Mittelalterliche Architektur im Preussenland, p. 670 (on p. 671 there are more literature given concerning the church). The tower, originally an element of the city walls, was incorporated into the church building between 1370s and 1380s. It is not quite certain whether it existed or was finished in the middle of the 1370s when building work started on Bezławki castle. Initially, it was 20 metres high and then in the first half of the $15^{\text {th }}$ century another 20 metres were added to it, see Dehio-Handbuch der Kunstdenkmäler West- und Ostpreußen. Die ehemaligen Provinzen West- und Ostpreußen (Deutschordensland Preußen) mit Bütower und Lauenburger Land (further cit. Dehio (A)), bearb. v. Michael Antoni, München-Berlin 1993, pp. 511-512. 
communication took place between Bezławki castle and Rastenburg castle. ${ }^{73}$ If the signals were only sent from Bezławki castle to the parochial church tower then one can assume that the communication between the castles was possible only when employing some organs of Rastenburg borough because even though St. George's church was under the patronage of the Teutonic Order ${ }^{74}$ it was one of the elements of the city walls together with its enormous tetragonal tower located in the southwest corner exposed to the circuit city walls from the south west corner and was protected by armed men appointed by the city council and not by the Order. In the light of the above we cannot exclude the church from the communicational network that might have existed between the castles of Bezławki and Rastenburg. All of this is conjecture and no proof of such communication exists and thus more research needs to be undertaken.

Apart from Rastenburg, Brillowski depicts a probable communication system including Bezławki castle and mentions the town of Rößel (Polish: Reszel) with the bishop's castle which was most probably visible from the north-west side of the castle house. Some simple mathematical-geodesic calculations together with cartographic analysis prove this was false. ${ }^{75}$ Even if Rößel was some $55 \mathrm{~m}$ high build-

\footnotetext{
${ }^{73}$ According to the archeological and architectonical research of the castle it did not all have a tower in the $15^{\text {th }}$ century (a round tower was erected in the north-west corner of the courtyard in 1622), see BKDPOP, H. 2, pp. 150-151; Dehio (A), p. 510; Jan SAlm, Kętrzyn, [in:] Leszek KaJzer, Stanisław KoŁodziejski, Jan SALm, Leksykon zamków w Polsce, ed. Leszek Kajzer, Warszawa 2001, p. 225; Ch. Herrmann, Mittelalterliche Architektur im Preussenland, pp. 668-669.

${ }^{74}$ In a count of Marienburg convent's members around 1448-1450 the priest in Rastenburg is mentioned, also the presbyter-the member of the Teuonic Order holded this office undoubtedly at the parish church; see GStA PK, XX.HA, OBA 28323, fol. 1v (printed in: M. Lucas David's HofGerichts-Raths zu Konihsberg unter dem Marggrafen Albrecht Preussische Chronik, hrsg. v. Ernst HeNNIG, Bd. 6, Königsberg 1814, p. 93, footnote 2, pp. 93-96; see also Sławomir Jóżwiak, Liczebność konwentow zakonu krzyżackiego w Prusach w pierwszej połowie XV wieku, Zapiski Historyczne, vol. 72: 2007, no. 1, p. 17.

${ }^{75}$ The distance between Bezławki castle and the castle in Rößel is $8630 \mathrm{~m}$. The castle house of Bezławki is situated 128 metres above sea level and the Rößel castle at 115 metres. It provided an overview of the area from the attic level of the founding of the castle house, which was at a height of $15 \mathrm{~m}$ (143 m above the sea level. It is also possible that after 1370-1380 (along with upgrading the main tower; comp. next footnote) such a possibility existed in Rößel castle at a height of $18 \mathrm{~m}$ (133 m above sea level). If the area had been flat, visibility between them would have been definitely possible. If the area at an orthodromic distance connecting two points was flat, the visibility between them would have been very clear. However the orthodroma between Bezławki and Rößel runs through an area of 140 metres above sea level high (the moraine debris west of Wirbel lake) and additionally covered by a spruce forest (both now and most probably in the $18^{\text {th }}$ century (see Karte von Ost-Preussen nebst Preussisch Litthauen und West-Preussen nebst dem Netzdistrict. Aufgenommen unter Leitung des Königl. Preuss. Staatsministers Frey Herrn voN SCHRÖTTER in den Jahren 1796 bis 1802 (further cit. Schroetter (oryg.)), Staatsbibliothek zu Berlin Preußischer Kulturbesitz, Haus Unter den Linden, Kartensammlung, Kart. N 1020, Blatt 48) and probably in the $14^{\text {th }}$ century too). The above together with a 15 metre-high forest reaching $15 \mathrm{~m}$ high, exclude any signal communication not only between the castles but also between the castle house and any other building in Rößel smaller than $55 \mathrm{~m}$. The tower of St. Peter and Paul's parish church was initially much shorter (in the form from 1360-1380) and was increased to $45 \mathrm{~m}$ high probably in the 1440 s or again during a new phase of the building
} 
ing (which we cannot be sure of ${ }^{76}$ the functioning of a communication network, similar to the one described with regards to Rastenburg, seems to have been even less probable. Rößel was under the auspices of Bishops of Ermland so the military power of the Teutonic Order and the possibility of issuing orders by the Teutonic Order's brothers with Grand Master at the head was limited and dependent on existing situations and circumstances. ${ }^{77}$ On the basis of the ways the routes for delivering letters on Warmia issues were established it can be clearly seen that the Order rarely used the fortified buildings located on the bishops' demensne or Ermland chapter as a precautionary measure. ${ }^{78}$ All in all, such precautions were in effect for numerous reasons (the letters were being delivered by people who did not belong to the corporation), but also the issue of who was in power. What is more, for the Order, the bishops were both close and distant and even despite feelings of communality within Prussian country they would in turn compete or argue with

work which started in 1484 and finished in 1503, see Georg Matern, Die Pfarrkirche SS. Petri und Pauli in Rößel, Königsberg i. Pr. 1930, pp. 4, 6, 11, 22-23, 26-27; Adolf Poschmann, 600 Jahre Rößel. Bilder aus alter und neuer Zeit: 1337-1937, Rößel 1937, pp. 116-118; Ch. Herrmann, Mittelalterliche Architektur im Preussenland, p. 692 (the author is not very precise about the erection of the tower in the second half of the $15^{\text {th }}$ century as it was only being renovated back then and alternatively made higher. Also the tower which was built within the Augustine monastery in 1370-1371 was not higher than $50 \mathrm{~m}$ and a little lower to the level of the castle buildings as the level of th eastern part on which the castle and the town were located was leaning slightly northwards; see Adolf Poschmann, Das Augustinerkloster in Rößel, Zeitschrift für die Geschichte und Altertumskunde Ermlands (further cit. ZGAE), Bd. 24: 1930-1932, pp. 86, 187 and Abb. 1; idem, 600 Jahre Rößel, pp. 141-142.

${ }^{76}$ The highest element of the castle was the main tower ("bergfryd") built circa 1350/1353-1355 on the north west part of the hill, in the plan of the square, in the north west corner of the castle defence earth walls and increased in height to $18 \mathrm{~m}$ around the 1380 s or 1390s, see G. MAtern, Burg und Amt Rößel, pp. 17-18; A. Poschmann, 600 Jahre Rößel, p. 16; Hanna Domańska, Zamek biskupów warmińskich w Reszlu), Rocznik Olsztyński, vol. 8: 1968, p. 110 (writes that the height of the building "bergfryd" reached the fifth level); eadem, Proces modernizacji średniowiecznych zamków z terenu państwa krzyżackiego w XV-XVIII wieku), Studia i Materiały do Historii Wojskowości, vol. 17: 1971, no. 2, p. 30; Izabella BRzostowskA, Die Haupttürme der Burgen in Heilsberg und Rössel - zwei gegensätzliche Werke in Wehrarchitektur Ermlands, [in:] Echte Wehrhaftigkeit oder martialische Wirkung. Zur praktischen Funktion und zum Symbolcharakter von Wehrelementen profaner und sakraler Bauten im Deutschordensland Preußen und im Ostseeraum, hrsg. v. Gerhard EIMER, Ernst GierLich (Kunsthistorische Arbeiten der Kulturstiftung der deutschen Vertriebenen, Bd. 3), Köln 2000, p. 106; Ch. Herrmann, Mittelalterliche Architektur im Preussenland, p. 689. Only at the begining of the $16^{\text {th }}$ century was there another 7-8 metres added to it, see Ch. HerrmanN, Mittelalterliche Architektur im Preussenland, p. 689.

${ }_{77}$ Brigitte Poschmann, Bistümer und Deutscher Ordens in Preussen, 1243-1525. Untersuchung zur Verfassuns- und Verwaltungsgeschichte des Ordenslandes, Münster 1962, pp. 45-81; Jan Ртак, Wojskowość średniowiecznej Warmii (Rozprawy i Materiały Ośrodka Badań Naukowych im. Wojciecha Kętrzyńskiego w Olsztynie, no. 172), Olsztyn 1997, pp. 65-72.

${ }^{78}$ Jürgen Jahnke, Heinz Zimmermann, Die Postwege des Deutschen Ordens in der ersten Hälfte des 15. Jahrhunderts (Erläuterungen zur Karte), [in:] Historisch-geographischer Atlas des Preußenlandes, hrsg. v. Hans Mortensen, Gertrud Mortensen, Reinhard Wenskus, Lfg. 1, Wiesbaden 1968, pp. 1-11; Die Postwege des Deutschen Ordens (1. Hälfte 15. Jh.), bearb. v. Jürgen Jahnke, Heinz ZıмMERMANN, [in:] ibid., Teilblatt 4, 5 . 
each other in the $14^{\text {th }}$ and the beginning of the $15^{\text {th }}$ centuries. ${ }^{79}$ One could argue the point that Ermland's fortified buildings were included by Teutonic Order's knights in the local signal communication network which thanks to the aformentioned sense of community and because as such it was safe however even when such cooperation took place using them never became common practice.

To make the discussion on possible communication between Bezławki castle and neighbouring strongholds complete it should be pointed out that signal communication was not possible either between the castle in Seehesten (Polish: Szestno $)^{80}$ built in the 1360 s/1470s or the castle in Ryn, which started being erected in $1377 .{ }^{81}$

If we consider the recognised connections between Bezławki castle and fortified buildings in Rastenburg as including the town fortifications (with the church) and the castle it could be tentatively opined that there functioned in the 1390s a local, two- or (more probably) three- elements defence arrangement. It is up to the future researchers to find an explanation or evidence regarding whether the Teutonic Order castle in Lamgarden (Polish: Garbno) which is located north west of Rastenburg 82 could have been a part of it.

While the existence of a defence system consisting of a group of a few fortresses/strongholds around Rastenburg is open to doubt, there is more likelihood of the functioning in the Teutonic Order's time of a number of oblong fortifications

${ }^{79}$ Franz FLeISCHER, Heinrich IV Heilsberg von Vogelsang, Bischof von Ermland (1401-1415), ZGAE, Bd. 12: 1899, pp. 20-22; Victor RöHRICH, Geschichte des Fürstbistums Ermland, Braunsberg 1925, pp. 165-172, 175-178; B. Poschmann, op.cit., pp. 35, 69, 92-96, 99-101; Alojzy SzorC, Dominium warmińskie 1243-1772. Przywilej i prawo chełmińskie na tle ustroju Warmii (Rozprawy i Materiały Ośrodka Badań Naukowych im. Wojciecha Kętrzyńskiego w Olsztynie, no. 112), Olsztyn 1990, pp. 24-25; Andrzej Radzimiński, Der Deutsche Orden und die Bischöfe und Domkapitel in Preußen, [in:] Ritterorden und Kirche im Mittelalter, hrsg. v. Zenon H. NowaK (Ordines Militares - Colloquia Torunensia Historica, vol. 9), Torun 1997, pp. 44-45 (resumption: idem, Kirche und Geistlichkeit im Mittelalter. Polen und der Deutsche Orden in Preussen (Ecclesia clerusque temporibus medii aevi Polonia et Ordo Teutonicus in Borussia), Torun 2011, pp. 369-372; Polish translation: Zakon krzyżacki a biskupi i kapituly w Prusach XIII-XV w., [in:] idem, Kościół i duchowieństwo w średniowieczu. Polska i państwo zakonu krzyżackiego w Prusach (Ecclesia clerusque temporibus medii aevi Polonia et Ordo Teutonicus in Borussia), Torun 2012, pp. 320-322. It should be stressed that the number of conflicts grew after the year 1411 .

${ }^{80}$ BKDPOP, H. 6, p. 99-100; Dehio (A), p. 582; Ch. Herrmann, Mittelalterliche Architektur im Preussenland, pp. 726-727.

${ }^{81}$ See BKDPOP, H. 6, pp. 83-84; Dehio (A), pp. 526-527; Tomasz Torbus, Die Konventsburgen im Deutschordensland Preußen (Schriften des Bundesinstituts für ostdeutsche Kultur und Geschichte, Bd. 11), München 1998, pp. 237-239, 609-614; idem, Zamki konwentualne, pp. 270, 272-273; Ch. Herrmann, Mittelalterliche Architektur im Preussenland, p. 678.

82 [N.] WulfF, Lamgarben und Cremitten. Zwei historische Fragezeichen, AM, Bd. 6: 1869, pp. 369-370; BKDPOP, H. 2, pp. 110-112; Dehio (A), p. 347; K. H. Clasen, Die mittelalterliche Kunst, Bd. 1, p. 141; who dates the stronghold to the same period, which in the case of Bezławki falls around 1400 - agreeing with the suggestions in the light of the analysis made by the Koperkiewicz's team we should maybe go back about two decades when dating the building work in Lamgarben. However before wide archeological studies are conducted this is only an assumption. 
filled with artificial barriers in the neighborhood possibly with prepared and maintained observation posts which could have been functionally connected with both local strongholds and as a result complete a local defence system. These were called "landwer" or "landwere" which was a Middle Age term functioning in German language circles and commonly used in Prussia country in number of meanings; the modern, scientific equivalent would be "oblong fortifications"). ${ }^{83}$ "Landwere" could take all possible morphological shapes. In its simplest form it was a clearance created with the branches of cut trees and twigs placed in a certain way (German: Verhau) and their effectiveness was due to their depth ${ }^{84}$ or by the way the trunks were cut to a certain length and bushes positioned between them with the addition of bits of the cut parts of trees which created some kind of a hedge (German: Hag, Hagen, Gehage). ${ }^{85}$ In late medieval terminology of the Midle High and Midle Low German both kinds of clearance, frequently occurring together, are described by the terms: "hac," "hage," "hege" or "hagen." ${ }^{\prime 6}$ In the light of fortification terminology one cannot definitely decide whether they acted as obstacles (barriers) with the role of slowing down the invaders or as posts for armed men. ${ }^{87}$ The more complicated form of "landwere" were long-line earthworks (German: Landwälle, Erdwälle) $)^{88}$ additionally supported depending on what was needed and the technical possibilities available with wooden, stone or turf elements. They were a few metres high and usually accompanied by a quasi automatically depending on geomorphology created moat on their outer side. They might have been a kind of barrier, however, most frquently they were erected as posts for active defence. Their

${ }^{83}$ A. von Cohausen, op.cit., pp. 8-20,73-76, 233-236; uses narrow semantic term "Landwehr," which describes a oblong fortifications comprising of bulwark and ditches (moats) however the medieval and early modern times sources leave no doubt to that the term "landwer" was used to defin oblong fortifications of any structure and type; this wider meaning is stressed by: Eduard Pelissier, Der gegenwärtige Stand der Landwehrforschung, Deutsche Geschichtsblätter, Bd. 11: 1910, H. 1, pp. 12-15; Hans Beschorner, Literatur zur Landwehrforschung, ibid., Bd. 11: 1910, H. 5, pp. 125-127. In the light of typology and terminology introduced in Polish literature by Elżbieta Kowalczyk (comp. eadem, Systemy obronne wałów podłużnych we wczesnym średniowieczu na ziemiach polskich (Biblioteka Archeologiczna, vol. 26), Wrocław-Warszawa-Kraków-Gdańsk-Łódź 1987, pp. 13-15) the limited application of the term "Landwehr" would refer to "oblong bulwark" however a wider usage functioning in the Middle Ages would have its equivalent in modern Polish terminology as oblong fortifications. The medieval understanding of the term "Landwer" was based on its functioning not morphology or way of constructing it. Such a function (quasi expletive) was fulfilled by other terms such as "hagen" or "verhau."

${ }^{84}$ A. von Cohausen, op.cit., p. 17. In Polish fortification's terminology such a clearance is referred to as "abates," see MSTDAO, p. 93; S. FuglewiCz, op.cit., pp. 5a-b; E. KowALCZYK, op.cit., p. 16.

${ }^{85}$ A. von Cohausen, op.cit., pp. 8-9, 11-12; E. Kowalczyк, op.cit., p. 16.

${ }^{86}$ Mittelhochdeutsches Wörterbuch, mit Benutzung des Nachlasses v. Georg Friedrich BENECKE ausgearb. v. Wilhelm Müller, Friedrich ZARncke, Bd. 1 (A-L), Leipzig 1854, pp. 606b-607a; MHDHWB, Bd. 1 (A-M), Leipzig 1872, pp. 1136-1137, 1142-1143; MNDWB, Bd. 2 (G-L), Bremen 1876, pp. 223-224.

${ }^{87}$ Regarding the terminology see MSTDAO, pp. 69, 74; S. FuglewiCz, op.cit., p. 4 a.

${ }^{88}$ August von Cohausen, op.cit., pp. 70-71; E. Kowalczy , op.cit., pp. 19-23 
barrier or defend potential was strengthened by adding on its top or outer side or berm a palisade. ${ }^{89}$ In the second half of the $19^{\text {th }}$ and the first decades of the $20^{\text {th }}$ centuries historians, archaeologists and Prussian regional scientists located a number of places where such forms of longwall fortifications or at least their remnants were preserved. For the last few decades Polish researchers have been conducting field studies and in the last few years intensifying their interest in these objects.

There was quite fruitful research conducted in the environs of Bezławki and Kętrzyn (Rastenburg) by Carl Beckherrn, ${ }^{90}$ Freiherr von Bönigk, ${ }^{91}$ Georg von Bujack, ${ }^{92}$ Emil Hollacka ${ }^{93}$ and Hans Crome ${ }^{94}$ where they managed to indicate a number of potential places along which there might have been lines of longwall fortifications (such places were among others: Wopławki (German: Woplauken), Wymiarki (Damerau, German: Charlottenberg), Porębek (German: Prömbock), Kwiedzina (German: Queden), Osewo (German: Wossau), Budziszki (German: Budzisken) and Pilec (Walkenhayn, German: Pülz). Their detailed description and cartographic location would demand a separate study as well as extra archeological and areal investigation ${ }^{95}$ without which nothing certain can be stated either about their range, length, morphology or chronology. ${ }^{96}$ Only an accumulation of this data will assist in analysis and interpretation and help in the search for these $14^{\text {th }}$ century defensive structures which might have been elements of local defence systems.

${ }^{89}$ C. Beckherrn, Das Ordenshaus Bäslack, p. 639, footnote 3, pp. 638-639; referred to known from German language regions ways of strenthening of bulwarks by adding bushes to the sides and on the tops ("Strauchwerk"). Therefore it was connexion of oblong bulwark with hedge.

${ }^{90}$ C. BeCKherrn, Das Ordenshaus Bäslack, pp. 637-642 (The Prussian regional historian wrote about "wildhauses" as fortified points from the central regions of the Prussian country constituting "long lines of Landwer" (pp. 637, 638).

${ }_{91}$ FreIHERR VON BÖNIGK, Ueber Landesvertheidigung nach Osten im ersten Jahrhundert der Ordensherrschaft (Sitzung [der Alterthumsgesellschaft Prussia] vom 16. Januar 1880), AM, Bd. 18: 1881, pp. 150-159.

${ }_{92}$ Georg von BUJACK, Über die Burgwälle in der Umgegend von Rastenburg, AM, Bd. 13: 1876, pp. 681-684; idem, Über die Grenzgebiete des alten Bartener Landes mit ihren Erinnerungen an die heidnische Zeit, AM, Bd. 15: 1878, pp. 161-163.

${ }^{93}$ Vorgeschichtliche Übersichskarte von Ostpreussen. Im Auftrage des ostpreussischen ProvinzialVerbandes, entw. u. gezeichn. v. Emil Hollack, Glogau-Berlin 1908; Erläuterungen zur vorgeschichtlichen Übersichtskarte von Ostpreußen, bearb. u. hrsg. v. Emil Hollack, Glogau-Berlin 1908, pp. 124, 125, 187.

${ }^{94}$ Hans Crome, Verzeichnis der Wehranlagen Ostpreußens, Tl. 1, Prussia, Bd. 32: 1938, pp. $182-$ 183; Tl. 4, Prussia, Bd. 34: 1940, pp. 104, 105, 143.

${ }^{95}$ The region of the Ermland-Galindian and Ermland-Barten borderland has been since a dozen or so years under the investigation of Robert Klimek, see idem, Waly podłużne w Nerwiku, gmina Purda, województwo warmińsko-mazurskie, Pruthenia, vol. 1: 2006, pp. 109-125; idem, Funkcjonowanie i obecny stan zachowania średniowiecznych wałów podłużnych w południowej części dominum warmińskiego), Pruthenia, vol. 3: 2008, pp. 163-206.

${ }^{96}$ A few introductory comments made by S. Szczepański (op.cit., pp. 19-20), based on information from R. Klimek and a few references made to the older German language literature cannot be viewed as a sufficient analytical conceptualisation of the issue. 
It is time that the question of the essence of the alleged or real Rastenburg defence system is answered and what were its overarching functions. A definitive answer cannot be furnished without proper research. The above analysis focuses attention on its communicational function and its military dimensions and meaning. Distant signal messaging, if existing, had to be based on the uniform set of codes which made information about the alleged danger travel fast to all the places at the same time. This in turn would have affected the effectiveness and speed of actions undertaken to prepare for defence and/or of informing the surrounding villagers about danger or at lastly? of undertaking some preventive measures. The military significance of such systemic communication is unquestionable.

The second possible overarching military function of the possible local defence system might have been connected with blocking some key communication points (if not all of them) or even communication channels (i.e. crossing obstacles place on the routes). If it is to be assumed that each single fortified point protected only one key or channel communication point and might have been missed by the approaching enemy thus heading towards the nearest neighbouring passage, then the ensemble of fortifications erected in that points enabled synchronised in time defence and if the need arose the defence of the whole line of defence if not all key and channel communication points leading to the defended region. The natural environment of late medieval Prussia, densely covered with forest, a hydrographic network of waters and a variety of land forms fostered the fortification of communicational routes in their key and channel points. The surroundings around Rastenburg was no exception. The "system" character of the neighbouring fortified buildings could have been decided upon because of the aforementioned longwall fortifications and the "system" function of "wildhauses," as stated by Koperkiewicz which might have existed "to act as key defence points in the lines of earthworks" protecting and blocking the main communication points or channels ${ }^{97}$ which in reference to bigger fortifications was also a point stressed by M. Arszyński. ${ }^{98}$ All these assumptions need to be verified by further research and analysis.

To finish off these musings on the functioning of fortified buildings on the eastern edges of late medieval Prussia one has to state that in the light of all the critical comments made about the possible existence of systems consisting of a small number of elements and on the basis of existing knowledge about civilisation capabilities of land populace it is hard to imagine that the Teutonic Order could have created one big defence system. On one hand it cannot completely be ruled out that such a possibility came to pass but on the other hand due to a lack of appropriate conditions it should not be considered. Phrases related in scientific literature to "one defence system" in Prussia" ${ }^{99}$ should be viewed as taken either from everyday language instead of proper terminology, or related to a "romantic"

\footnotetext{
${ }^{97}$ A. Koperkiewicz, Zamek w Bezławkach, p. 45.

${ }^{98}$ M. ArszyŃski, Die Deutschordensburg als Wehrbau, p. 95.

${ }^{99}$ See above pp. 11-12.
} 
vision of the medieval past from the $19^{\text {th }}$ century, or at last as signs of scientific imprecision.

\section{WILDHAUS AS A MORPHOLOGICAL TYPE OF FORTIFIED POINT?}

Before tackling the third question which deals with looking for the specific morphological structure in "wildhauses" the observation needs to be made that research on the fortified buildings in late medieval Prussia has been done around some analytical patterns. There has been some agreement on the homogeneous typology applied to buildings erected by the Prussian branch of the Teutonic Order. This typological scheme combined both morphological and administrative criteria.According to the researchers there were two, three or four types of offices dealing with administration of the country and they functioned alongside leaders residing in two, three or four fortified types of fortified buildings. The commanders occupied the four-wing, tetragonal castles, referred to as "commanders' castles." In the smaller ones, usually consisting of one or two wings, the procurators (Pflegere) or reeves (Vögte) resided and in the smallest buildings, so called "castle houses" also referred by some researchers as only "a fortified backyard" were the places where Kämmerer lived (so called "Kämmerer castles" ${ }^{100}$ ). Other attempts have been

${ }^{100}$ Bernhard Schmid, Die Burgen des deutschen Ritterordens in Preussen, Berlin 1938, p. 12; idem, Die Burgen des Deutschen Ordens in Preußen, Deutsches Archiv für Landes- und Volksforschung, Jg. 6: 1942, H. 1-2, pp. 80-81; Carl Wünsch, Die Burgen des Deutschen Ordens in Preußen, [in:] Historisch-geographischer Atlas des Preußenlandes, Lfg. 1, pp. 7-8; M. HAfтKA, op.cit., p. 21; Marian ARszyŃsKi Architektura warowna zakonu krzyżackiego w Prusach, [in:] Fundacje artystyczne na terenie państwa krzyżackiego w Prusach. Katalog wystawy w Muzeum Zamkowym w Malborku 25 czerwca - 12 września 2010 roku, ed. Barbara PosPiEszna, vol. 2: Essays, Malbork 2010, p. 30 (this researcher, also in his other publications, points out [apart from commanders' castles] only a second common group of castles: reeves', procurators', woodruffs' and piscine masters' castles thereby stressing the morphological differences between them; see idem, Die Deutschordensburg als Klosterbau, [in:] Die Spiritualität der Ritterorden im Mittelalter, hrsg. v. Zenon H. Nowak (Ordines Militares Colloquia Torunensia Historica, vol. 7), Toruń 1993, p. 150; idem, Deutschordensburg, [in:] Lexikon des Mittelalters, Bd. 2: Bettlerwesen bis Codex von Valencia, Stuttgart-Weimar 1999, szp. 915; idem, Zamki i umocnienia krzyżackie, [in:] Państwo zakonu krzyżackiego w Prusach. Podziały administracyjne i kościelne w XIII-XVI wieku), ed. Zenon H. Nowak, Roman CzAJA, Toruń 2000, pp. 31, 42 (in the new, updated version: idem, Zamki i umocnienia zakonu krzyżackiego i hierarchii kościelnej w Prusach, [in:] Zakon krzyżacki w Prusach i Inflantach. Podziały administracyjne i kościelne w XIII-XVI wieku, ed. Roman CzajA, Andrzej Radzimiński (Dzieje Zakonu Niemieckiego, vol. 2), Toruń 2013, pp. 59-60, 74-75; idem, Architektura warowna państwa zakonnego, [in:] Małgorzata Jackiewicz-Garniec, Mirosław Garniec, Zamki państwa krzyżackiego w dawnych Prusach. Powiśle, Warmia, Mazury, Olsztyn 2006, p. 36); Ch. Herrmann, Burgen im Ordensland, pp. 35-36; idem, Mittelalterliche Architektur im Preussenland, pp. 80-81 (the author first analyses the functions the castles fulfilled then the morphological features and combines both ascribing certain architectonic structures to both "convent castles" ("Konventsburgen") and "castles of the officials" ("Amtsburgen"); see also some comments made by: Leszek KaJzer, Jan SALM, Polnische Forschungen über die Burgen im Gebiet des ehemaligen Deutschordensstaates. Eine Bilanz der letzten 50 Jahre, Castrum Bene, vol. 5: 1996 (Castle and Church), p. 81. Rigid but simultaneously expanded classification is present especially in popular science publications on fortifications in the late medieval Prussia and there is very 
made to define bigger number of types of fortified buildings based on their variety of shapes and outlines sometimes combining it with the tri-classification of castles' administration. Due to such a schematic way of looking at castles, convent castles are classified into the category of "ideal models." observable and later on settled according to which, the diachronical phenomenon of fortified buildings could explain all aberrations from "the ideal model." Thus, an evolutionary morphological-administrative typological model has come to prominence with the square shape and four-wing set being given pride of place in the hierarchy and thus the home of the commanders and as a result applying this form to types known as "commanders' castles." ${ }^{102}$ Within the last few years the drawbacks of such a categorization and analytical dogmatism have come to be seen resulting in researchers abandoning the two-criteria typological concept.

The practice of classifing fortified buildings is not solely the result of the analytical efforts of historiography today. The application of the term "wildhaus" from the middle of the $14^{\text {th }}$ century in addition to the term "hus" and along with them a third, "flyhus" ("a refuge house") ${ }^{103}$ shows that at that time in Prussia there was at

often even a four-type divison applied: commanders', reeves', procurators' and Kämmerer' castles, see Mirosław Garniec, Architektura i państwo - typy zamków Powiśla, Górnych Prus, Warmii i Mazur, [in:] M. JaCKIEWICZ-GarnieC, M. GarnieC, op.cit., pp. 40-41, 43-55; see also: Janusz BieszK, Zamki państwa krzyżackiego w Polsce, Warszawa 2010, pp. 13-16.

${ }^{101}$ K. H. Clasen, Die mittelalterliche Kunst, Bd. 1, pp. 8-9, 13-14, 29, 51, 73-74, 97, 118; idem, Entwicklung, Ursprung und Wesen der Deutschordensburgen, Jahrbuch für Kunstwissenschaft, Bd. 3: 1926, pp. 1-37; T. Torbus, Die Konventsburgen, pp. 144-145, 216; the same, see idem, Zamki konwentualne państwa krzyżackiego w Prusach, Gdańsk 2014, pp. 167-168, 243.

${ }^{102}$ K. H. Clasen, Die mittelalterliche Kunst, Bd. 1, pp. 73-76, 187-196, 208-210; M. Arszyński, Zamki i umocnienia krzyżackie, pp. 31, 42; idem, Zamki i umocnienia zakonu krzyżackiego, pp. 59-60, 74-75; idem, Architektura warowna państwa zakonnego, pp. 28-29; idem, Architektura warowna zakonu krzyżackiego w Prusach, pp. 16-17, 28; idem, Budownictwo warowne zakonu krzyżackiego w Prusach, s. 148-149; T. Torbus, Die Konventsburgen, pp. 124-127, 144-145, 177-180, 211-212; idem, Zamki konwentualne, pp. 141-144, 167-168, 203-206, 239; S. Gouguenheim, op.cit., s. 149.

${ }^{103}$ On the fact that some strongholds had their function described in $14^{\text {th }}$ century sources as a refuge in case of invasion, see i.a.: GStA PK, XX. HA, Ordensfoliant (further cit. OF) 107, fol. 131v $\sim$ OF 108, fol. 135v OF 111, fol. 69r (bl. 187r) (30 XI 1388: the castle in Wargen as a "flyhuß;" on the basis of this source: Dehio (G), p. 427; Erich Weise, Wargen, [in:] Ost- und Westpreussen, p. 235; and followed in popular science publication by Friedrich Borchert, Burgen, Städte, deutsches Land. Baudenkmäler in Ost- und Westpreußen und ihre Geschichte, Essen 1991, p. 38); GStA PK, XX. HA, OF 101, fol. 24r-24v (bl. 18r-18v) OF 102, p. 57 (27 IX 1327: Samland bishop's castle in Powunden was a place of refuge for the surrounding populace); Preußisches Urkundenbuch. Politische (allgemeine) Abteilung (further cit. PU), Bd. 6, Lfg. 2: 1367-1371, hrsg. v. Klaus Conrad, Marburg 2000, no. 820, p. 469 (9 V 1370: the castle in Schaaken as a refuge for its inhabitants); PU, Bd. 6, Lfg. 2, no. 821, p. 470 (9 V 1370, identical comment); GStA PK, XX. HA, OF 103, fol. 67 (bl. 68r) OF 104, fol. 4v (bl. 31v) (23 I 1360 - 17 III 1371: the castle in Powunden as a place of refuge); see in this context M. Arszyński's opinion on "shelter houses" ("Fliehhäuser"), [which were to be erected in the $13^{\text {th }}$ century mainly by the newly baptised Balts to gain protection against their pagan brethern, idem, Die Burgen im Deutschordensland Preußen, p. 106; the above examples prove that the basic refuge function of same fortified points did not last throughout the $14^{\text {th }}$ century and was also (and maybe above all) fulfilled by the dominion authorities (the Teutonic Order, bishops and bishops chapters). 
the very least a tripartite division of castles which could be today called "nomenclature" typology behind the naming - was based on typographic location, on size or the functions applied to it such as for example the refuge function it fulfilled. The answer to the question whether there existed any connection between strongholds classified in the $14^{\text {th }}$ century as "wildhauses" to any specific morphology of a fortified building and if we can nowadays connect nomenclature to morphology typology in the light of the analysis on the separate relationship between morphological and administrative criteria seems clear.

It is worth taking a closer look at the issue. In 1898 Adolf Boettischer pointed out, not adequately, the architectural similarities between Bezławki castle and the fortified building in Lamgarben (Polish: Garbno) where both had a courtyard surrounded by a curtain wall. ${ }^{104}$ As no archeological research has been carried out on Lamgarben it is difficult to verify such opinions but on the basis of A. Boettischer's schematic plan, at least two bedchamber towers (south-west and south-east) ${ }^{105}$ are observable. We have to stress that the much smaller courtyard in Lamgarben (30-32 $\times 27 \mathrm{~m}$; ca. 810-860 $\left.\mathrm{m}^{2}\right)$ when compared to Bezławki castle $(42,3 \times 51,8 \mathrm{~m}$; $2180 \mathrm{~m}^{2}$ ) limited Lambergen's refuge function. In Bezławki there was a stone-layed castle house while uncertainty remains about whether Lamgarben did. ${ }^{106}$ So all in all there are both similarities and differences between the two places.

Wojciech Wółkowski enumarates 14 fortified buildings in total which he sees as related in their layout to Bezławki. These include: Lyck (Old Polish: Łek, Polish: Ełk), Lamgarben, Gierdawy (German: Gerdauen, Russian: Žalaznodorožnyj), Aucliten/Wohnsdorf (German: Groß Wohnsdorf, Russian: Kurortnoe), Leunenburg (Polish: Sątoczno), Taplaki (German: Taplacken, Russian: Taplaki), Kaustritten (near Tylża), Krzemity (German: Kremitten, Russian: Lozovoe), Wargen (Russian: Kotelnikovo), Germau (Russian: Russkoe), Rudawa (German: Rudau, Russian: Melnikovo), Waldawa (German: Waldau, Russian: Nizov'e), Letzenburg (German: Lötzen, Polish: Giżycko) and Jasieniec/Jasiniec (German: Jaschienitz, Polish: Nowy Jasiniec). ${ }^{107}$ Their supposed common feature was a main stone-layed castle house with the curtain wall surrounding the courtyard.

Due to a lack of detailed archeological research, the outlines of most of the buildings are uncertain because they were often based on Johann Michael Guise's sketches from the late $1820 \mathrm{~s}^{108}$ which have not been verified. Neither an analysis

${ }^{104}$ BKDPOP, H. 2, p. 112.

${ }^{105}$ Ibid., p. 111; see also K. H. Clasen, Die mittelalterliche Kunst, Bd. 1, p. 141; W. WóŁKowsKI, op.cit., p. 111; W. BRILlowski, Analiza funkcjonalna założenia obronnego w Bezławkach, p. 133.

${ }^{106}$ Jan SAlm, Garbno, [in:] L. KaJzer, S. KoŁodziejski, J. SAlm, op.cit., p. 175.

107 W. WóŁKowski, op.cit., p. 113.

${ }^{108}$ On the two-year-long local activities of this Prussian military man see Johann/[Hans] CromE, Johann Michael Guise, sein Leben und sein Werk, Prussia, H. 27: 1926-1927, p. 62-63; idem, Weitere Nachrichten über J. M. Guise, den Wegbereiter ostpreußischer Burgwallforschung, Alt-Preußen, Jg. 3: 1938-1939, H. 3, pp. 91-94; Michael Malliaris, Die „Guise-Zettel“ aus dem Fundarchiv des PrussiaMuseums. Bilder „Vaterländische Altertümer” in Ost- und Westpreußen aus den Jahren 1826-1828, Preußenland, Jg. 41: 2003, No. 1, p. 8-13. 
of the morphological features of the buildings nor the chronological dynamics of their development can be undertaken. A closer examination of this information would require a seperate article which would entail more buildings unmentioned by W. Wółkowski and situated on the edges of the Prussia country at the turn of the $14^{\text {th }}$ and $15^{\text {th }}$ centuries being brought into the equation.

Wółkowski pointed out that the castle houses in Waldau and Taplacken ${ }^{109}$ were buildings in an architectural bay shape (sometimes constituting a high tenement house ('kemenate') with either a vertical or horizontal setup of rooms, ${ }^{110}$ which were included in at least one of the curtain walls surrounding the courtyard. Another similarity to Bezławki castle was the identical position of the castle house in regard to one of the curtain walls surrounding the courtyard. ${ }^{111}$ Taplacken castle was probably built in such a morphological shape after the old stronhold had been destroyed in $1376 .{ }^{112}$ There were also two corner bedchamber towers, not open keep towers, added as in Bezławki at the ends of the curtain wall, opposite to the castle house. ${ }^{113}$ The entrance gate was however located, unlike in Bezławki castle, on the opposite side of the curtain wall. ${ }^{114}$ Karl Heinz Clasen in his evolutionary concept of the building of fortifications in late medieval Prussia acknowledged the stronghold in Waldaw as "a forerunner" of Bezławki castle. ${ }^{115}$ The authors of the Gdańsk monograph did not undertake a more detailed analysis of the similarities and differences of both fortifications (apart from Wółkowski's aforementioned comment). In contrast to Bezławki the castle houses in Waldau were located on a zwinger surrounded by a separate wall, outside the circle of the curtain walls. ${ }^{116}$ Such structures were also (according to Anatolij Pavlovič Bahtin from the year 2001) used in Taplacken. ${ }^{117}$ As a result both Taplaclen and Waldau were much better fortified in comparison to Bezławki castle which was much better topo-

109 Замки и укрепления Немец,ого ордена в северной части Восточной Пруссии. Справочник, состав. Анатолий П. Бахтин, ред. Вадим Ю. Курпаков, Калининград 2005 / Zamki i ukrepeniâ Nemeckogo ordena v severnoi časti Vostočnoi Prussii, sostav. Anatolij P. BAhtin, ed. Vadim Û. Kurpakov, Kaliningrad 2005, p. 141; Ch. Herrmann, Deutschordensburgen in der „Grossen Wildnis”, p. 101, Abb. 5; idem, Mittelalterliche Architektur im Preussenland, p. 747; A. Koperkiewicz, Zamek $w$ Bezławkach, p. 51, pic. 6.

${ }^{110}$ See Leszek Kajzer, Dzieje zamków w Polsce, [in:] L. Kajzer, S. KoŁodziejski, J. Salm, op.cit., p. 29.

111 This similarity of the castle outlines in case of Bezławki and Taplaclen is stressed by A. KoPERKIEwICZ, Zamek w Bezławkach, p. 59; and by W. Brillowski, Analiza funkcjonalna założenia obronnego w Bezławkach, p. 123.

112 Wigand, cap. 87, p. 577 (also cap. 93, p. 583).

${ }^{113}$ K. H. Clasen, Die mittelalterliche Kunst, Bd. 1, p. 142; Замки и укрепления, р. 141

${ }^{114}$ K. H. Clasen, Die mittelalterliche Kunst, Bd. 1, p. 142; Замки и укрепления, p. 141. In Bezlawki it was built on the short, north-east part of the castle and the south-eastern part of the castle house, see W. Brillowski, Analiza funkcjonalna założenia obronnego w Bezławkach, pp. 123-124; W. Brillowski, A. Koperkiewicz, Archeological and Art. History Researh in Bezławki, pp. 37-38.

${ }^{115}$ K. H. Clasen, Die mittelalterliche Kunst, Bd. 1, p. 141.

116 Замки и укрепления, pp. 77-78.

${ }^{117}$ Ibid., p. 142. 
graphically located. The possible location of the entrance gate and the castle house opening to the courtyard seems more likely an element of Taplaki than Bezławki. Already noted and mentioned by K. H. Clasen as being a shared element of fortifications in Waldau and Bezławki are the open towers in the curtain wall surrounding the courtyard. ${ }^{118}$ However the significance of his observations is limited as the information about fortification morphology are not complete both regarding the location of fortified elements, the building materials used and sometimes even about the size.

In regards to other fortified buildings mentioned by Wółkowski, their similarities to Bezławki castle are not so clear thus ambigious. There is some probability that the castle houses which was included in the circle of the curtain wall existed in Kremitten (Old Polish: Krzemity) ${ }^{119}$ and Lamgarben (Garbno), ${ }^{120}$ but their position in regard to the wall or their size are not clear.

Regarding Letzenburg (Giżycko) it can be assumed that around the castle house built around 1384-1390 a palisade or (secondarily?) a curtain wall ${ }^{121}$ was erected so the main building of the defence structure was positioned in the created courtyard. ${ }^{122}$ Whether the same held in Lyck (Ełk), where the tower building was erected since $1398^{123}$ is unknown however it is improbable due to its island location.

In Germau in turn the castle house was probably a part of the defence arrangement in that its south girdle wall constituted a $70 \mathrm{~m}$ long part of the south curtain wall. ${ }^{124}$ As a result the outline of this castle looks more like the horizontal

${ }^{118}$ K. H. Clasen, Die mittelalterliche Kunst, Bd. 1, p. 141; Замки и укрепления, pp. 78-79.

${ }^{119}$ K. H. Clasen, Die mittelalterliche Kunst, Bd. 1, p. 142; Замки и укрепления, p. 177. However, in this case there were lower parts of two open towers preserved/saved on both ends of one oft he curtains of the wall surrounding the courtyard.

${ }^{120}$ See above p. 25.

${ }^{121}$ Joanna WAŃкошsка-Soвıеsıак, Badania architektoniczne zamku w Giżycku, WarmińskoMazurski Biuletyn Konserwatorski, vol. 4: 2002, p. 80 (the relics of the palisade were interpreted by the author as the traces of the Old Prussian defence works however Jerzy M. Łapo and Grzegorz Białuński have recently been right paying attention to the fact that the remains might have been parts of the Teutonic Order's fortifications, which (as the second location of Letzenburg) was situated on the place of former stronghold of Ysegup, the Balt tribe' nobleman; see Jerzy M. ŁAPO, Pradzieje okolic Giżycka, [in:] Giżycko. Miasto i ludzie, ed. Grzegorz BIAŁuński, Giżycko 2012, pp. 27-28; Grzegorz BIAŁUŃski, Trudny początek. Dzieje do 1612 roku, [in:] ibid., p. 50); Jan SALM, Giżycko, [in:] L. KAJZER, S. KoŁodZIEJSKI, J. SALM, op.cit., p. 175.

${ }^{122}$ A similar morphology could be applied to the castle in Jasieniec/Jasiniec (Jesnitz) on the Pommerania-Kuyavia border mentioned by W. Wółkowski, see Jan Salm, Nowy Jasiniec, [in:] L. KaJzer, S. KoŁodziejski, J. SALm, op.cit., pp. 327-328.

${ }^{123}$ Max Meyнöfer, Lyck, [in:] Ost- und Westpreussen, p. 127; Tomasz WiLde, Architektura zamków wschodniego pogranicza państwa krzyżackiego w świetle badań architektoniczno-archeologicznych, Rocznik Przedsiębiorstwa Państwowego Pracownie Konserwacji Zabytków, 1987 [1988], b. 2, p. 129; Jan Salm, Ełk, [in:] L. KaJZer, S. KoŁodziejSki, J. Salm, op.cit., p. 170.

${ }^{124}$ This is how the location of the castle house is interpreted by A. P. Bahtin, see Замки и укреnления, p. 107, pic. 150; similarly earlier in: BKDPOP, H. 1: Das Samland, Königsberg 1898, p. 54 (the castle house in the $16^{\text {th }}$ century turned into a church was to occupy the southern wing of the castle). However according the J. M. Guise' sketches the castle house was located within the curtain wall, bor- 
projection of Seehesten castle (Polish: Szestno) ${ }^{125}$ which was not mentioned by Wółkowski. A similar architectural structure might have existed in the case of the castle in Rudau - the castle house on one side reaching with its gable as far as the neighbouring curtain wall on the other side finishing half way of the length of the curtain wall supporting it. What is more, the courtyard was in the shape of a rectangle with one cut corner which was a way of adjusting it to the topographical conditions. ${ }^{126}$

The stone defence buildings in Wargen ${ }^{127}$ and Johannisburg (Polish: Pisz) ${ }^{128}$ had a completely different morphology. In the case of the latter the possibility cannot be ruled out that older defence structures might have had the shape of the castle house which was part of the curtain wall. In addition, from 1326 the castle in Leunenburg (Polish: Sątoczno) exemplified a different type of a fortified building. The one-bay castle house was planned to be built in the shape of a trapezoid (size $16,1 \times 26,3 \mathrm{~m}$ ), placed probably on top of an earth mound surrounded by a moat on three sides while on the fourth there was a steep embankment leading to the River Sajna. Next to the mound there was a fortified building with a rectangular layout (with one corner cut, in the place of a mound of large size $(73 \times 93 \mathrm{~m})$ with a palisade moat and one more palisade which was used as a defensive post as it was filled in with a porch. ${ }^{129}$ The castle house was then, not linked to the courtyard and

dering one top (of $18 \mathrm{~m}$ long) to the west part of the curtain wall, see BKDPOP, H. 1, p. 54, Abb. 33). This is still awaiting some further clarification.

${ }^{125}$ Jan Salm, Szestno, [in:] L. Kajzer, S. KoŁodziejski, J. Salm, op.cit,, p. 480; Ch. Herrmann, Mittelalterliche Architektur im Preussenland, pp. 726-727. Here the castle house had the length of $(25 \mathrm{~m})$ equal to the length of the side of the square which was the base of the whole fortitied point so that the three sides of the girdle wall were also parts of the curtain wall. In this case the results of archeological-architectonical research conducted in 1984-1986 by Marian Głosek' team showed a different picture to the one from J. M. Guise' sketches, see BKDPOP, H. 6, p. 100, Abb. 55; Fritz STOMвеR, Haus Seehesten, [in:] Unsere masurische Heimat. Zum hundertjährigen Bestehen des Kreises Sensburg, hrsg. v. Karl Templin, Sensburg 1926 (ed. 2), p. 118.

${ }^{126}$ BKDPOP, Н. 1, pp. 140-142; Замки и укрепления, pp. 104-105

${ }^{127}$ BKDPOP, Н. 1, pp. 165-166; Замки и укрепления, pp. 109-110.

${ }^{128}$ Joanna MACıEJEwsKa, Z dziejów zamku krzyżackiego w Piszu, Komunikaty Mazursko-Warmińskie, 1960, nr 2 (68), p. 235 (however the authoress only presents materials from the written records (with a lot of factual mistakes), not undertaking the issue of the morphology of the castle's arrangement); Jan Salm, Pisz, [w:] L. Kajzer, S. KoŁodziejski, J. Salm, op.cit., p. 386; Ch. HerrMann, Mittelalterliche Architektur im Preussenland, pp. 497-498.

${ }^{129}$ BKDPOP, H. 2, p. 117-118; Dehio (A), p. 369; in reference to the two-phase archeological, geophysical and geomorphic research from the years 1993-1995 and 2000-2002) of Leuenburg castle see Jerzy Siкorski, Sątoczno. Geneza i funkcje zamku oraz charakter osady, Warmińsko-Mazurski Biuletyn Konserwatorski, R. 1: 1999, p. 63-83; Aleksander Andrzejewski, Leszek KaJzer, Sprawozdanie $z$ badań archeologiczno-architektonicznych przeprowadzonych na terenie zamku w Satocznie, gm. Korsze, woj. warmińsko-mazurskie w 2001 roku, Łódzkie Sprawozdania Archeologiczne, vol. 7: 2001, pp. 289-307; iidem, Zamek krzyżacki w Satocznie, gm. Korsze w świetle badań terenowych w 2002 roku, ibid., vol. 8: 2002-2003, pp. 237-251; iidem, Z badań Instytutu Archeologii Uniwersytetu Łódzkiego nad zamkami na terenie województwa warmińsko-mazurskiego, [in:] Pogranicze polskopruskie i krzyżackie, ed. Kazimierz Grążawski, Włocławek-Brodnica 2003, pp. 227-231; iidem, The 
surrounding palisade by the only denfensive enceinte, but presented a well known from France type of fortified building (and dwelling-place too) known as a "motteand-bailey." ${ }^{130}$ It is difficult to look for morphological or architectural similarities to Bezławki castle and if Brillowski stresses the similarities of the layout between Bezławki and Leunenburg ${ }^{131}$ then it is nothing but an unacceptable simplification. The only analogy between the two buildings is the similar size of the castle house nothing more. The foundations of the building in terrain are different and so are other alternative elements.

Not enough is known about the stronghold in Gerdauen to state whether the castle house was the only building in the castle or if there were any others (as for example Dansker mentioned by Bahtin ${ }^{132}$ ). In reference to the fortified buildings of Aucliten/Wohnsdorf ${ }^{133}$ and in Kaustritten ${ }^{134}$ it is possible to define only their general outline.

Due to limited space permitting not even a quick mention of a number of other fortified buildings located in the eastern edges of late medieval Prussia (such as Schaaken, Russian: Nekrasovo), Tammow (Russian: Timofeevka), Nordenburg (Old Polish: Nordembork, Russian: Krylovo) and Jegławki (German: Jeglacken)) can be made and even a cursory inspection shows a much bigger morphological variety of the buildings mentioned by the Warsaw researcher than can be deduced from his article. As a result it is difficult to classify the strongholds mentioned by him into one category regardless of which typological criteria are applied. If analysis of the buildings used by Kämmerer ${ }^{135}$ is put together then it turns out that

Castle at Sątoczno in ",terra Barthensi” or praise of history, [in:] Castella Maris Baltici, Bd. 7 (Beiträge der Tagung „Die Stadt als Burg. Architektur-, rechts- und sozialhistorische Aspekte befestigter Städte im Ostseeraum vom Mittelalter bis zur frühen Neuzeit", 03.-06. September 2003 in Greifswald), hrsg. v. Felix Bierman, Matthias Müller, Christofer Herrmann, Greifswald 2006, pp. 9-14; iidem, Zamek w Satocznie w „Terra Barthensi” albo triumf historii, [in:] XIV Sesja Pomorzoznawcza, ed. Henryk PANer, Mirosław Fudziński, [vol.] 2: Od wczesnego średniowiecza do czasów nowożytnych, Gdańsk 2005, pp. 197-204; iidem, Sątoczno i Sepopol. Dwa modele rozwoju osadnictwa, [in:] Pogranicze polsko-pruskie i krzyżackie (II), ed. Kazimierz Grąż̇̇sкI, Włocławek-Brodnica 2007, pp. 276-279; Piotr KITtel, Rekonstrukcja systemu fos zamku krzyżackiego w Satocznie, w gminie Korsze, w świetle sondowań geologicznych, Łódzkie Sprawozdania Archeologiczne, vol. 8: 2002-2003, pp. 253-263.

${ }^{130}$ The same interpretation is also presented by A. ANDRZEJEwski, L. KAJZER, Z badań Instytutu Archeologii Uniwersytetu Łódzkiego nad zamkami), p. 231.

${ }^{131}$ W. BRILlowski, Analiza funkcjonalna założenia obronnego w Bezławkach, p. 129. The researcher suggests a similarity between the systems of organising the defence as in both castles, where the fortification surrounding the courtyard were "the first line of defence." In Leunenburg it was possible on the condition that motte with the castle house was inaccesible from both sides, (i.e. from the north and east) so it could have been attacked only from the east or south. Otherwise the castle house was open to attack with no possibility of assisting its defenders.

132 Замки и укрепления, рр. 64-65.

${ }^{133}$ BKDPOP, Н. 2, pp. 14-15; Замки и укрепления, pp. 68-69.

${ }^{134}$ Kurt Forstreuter, Splitter, [in:] Ost- und Westpreussen, p. 213; Замки и укрепления, pp. $179-180$.

${ }^{135}$ The castles in Gerdauen and Leunenburg (Sątoczno) were the house of the commanders (however we do not know their morphological shape) and later on of the procurator and the wood- 
it is impossible to point to one morphological type of fortified buildings which fulfiled this administrative function. Categorising "wildhhaus" as "Kämmerer's castles" and "wildhauses" as a homogenous morphological type of fortified points is an oversimplification of late medieval Prussian reality which in turn can lead to overinterpetations and wrong conclusions. In reference to W. Brillowski’s far too optimistic opinion, where he refers to information gleaned from the investigation of Bezławki castle as the basis for a detailed morphological and architectural analysis of other "wildhauses"136 I would advise that restraint should be shown regarding such a jump.

The set of speculations dealing with the functioning of military aspects of Bezławki castle which have been presented in this article offer a path for further research which can be undertaken concerning smaller fortified buildings of late medieval Prussia. Undoubtedly, archaeological and architectonical projects of specific strongholds provide the basis for more detailed analysis. They should be however conducted by a wide circle of researchers who specialise in differing fields ranging from history, through the history of settlements, the archaeology of architecture and ending with geo and paleo-environmental research, all combined to verify differing hypotheses formulated within specific fields. One should however bear in mind the fact that in regards to research conducted on edifices from the so called historical periods, the interpretational context provided by history as a science remains primary, something which is very often neglected by teams of archaeologists.

In reference to Bezławki castle it is necessary to point out that the research conducted within its premises (from 2008-2012) was only partial and did not include archeological research of the inner element of the building (i.e. the castle house (presently the church). For all interested in widening their knowledge on fortifications building in late medieval Prussia may research into Bezławki long continue.

(trans. by Alicja and Tomas Anderson)

Received $31^{\text {st }}$ March 2016

Received in revised form $31^{\text {st }}$ May 2016

Accepted $26^{\text {th }}$ June 2016

\begin{abstract}
PhD Krzysztof Kwiatkowski
Institute of History and Archival Sciences

Nicolaus Copernicus University of Torun

e-mail: Krzysztof.Kwiatkowski@umk.pl
\end{abstract}

ruffs; in the castles of Letzenburg and Lyck there were procurators. The castles in: Rudau, Kremitten, Wargen, Germau, Waldau and Taplacken were used by Kämmerer whilst the administrative function of Lamgarben is unclear, and in the castles of Aucliten/Wohnsdorf and Kaustritten - like in Bezławki there was no administrative offcials. The stronghold of Aucliten/Wohnsdorf and maybe Lyck can also be for the time 1375-1400 classified as "wildhaus."

${ }^{136}$ W. BRILlowski, Analiza funkcjonalna założenia obronnego w Bezławkach, p. 121. 


\section{DAS (WILD)HAUS IN BEZŁAWKI (BAYSELAUKEN, BÄSLACK) - BEMERKUNGEN ZUM BEFESTIGUNGSBAU DES DEUTSCHEN ORDENS IM SPÄTMITTELALTERLICHEN PREUSSEN}

\section{Zusammenfassung}

Schlüsselwörter: Spätmittelalter, spätmittelalterliches Preußen, Ermland, Burgen, Befestigungsbau, Heerwesen des Spätmittelalters, Konflikte

Der vorliegende Artikel ist eine Zusammenstellung von Bemerkungen über die militärischen Aspekte des Baus und der Funktion der Deutschordensburg in Bäslack ("Bayselauken," Bezławki) in den letzten Jahrzehnten des 14. Jahrhunderts. Die in ihm enthaltenen Erwägungen nehmen Bezug auf die Ansichten, die von den Autoren eines 2013 herausgegebenen Sammelbands über den spätmittelalterlichen Siedlungskomplex in Bezławki geäußert worden sind. Darin wurden die Ergebnisse von archäologischen Untersuchungen vorgestellt, die in der Burg und in dem Dorf in den Jahren 2008-2012 angestellt wurden.

Die Bemerkungen in dem Artikel beziehen sich auf drei von sechs ausgewählten Problemen, die als besonders wichtig erachtet wurden. Während die Ansicht von der Verteidigungs- und Fluchtfunktion der Burg in Bäslack völlige Zustimmung findet, wird die Hypothese abgelehnt, die in ihr einen "befestigten Lagerplatz" für Truppen während der militärischen Unternehmungen des Ordens gegen litauische und ruthenische Gebiete sieht. Deshalb gibt es keinen Grund, ihr eine militärische Bedeutung von "strategischem" Ausmaß zuzuschreiben, wie dies die Autoren des Sammelbandes von 2013 getan haben. Im zweiten Teil des Artikels wird die Hypothese vom "Systemcharakter" der Komplexe von Befestigungsbauten an den östlichen Rändern Preußens infrage gestellt. Wenn die Burg in Bäslack überhaupt Teil irgendeines Verteidigungssystems war, dann kann dieses nur einen sehr lokalen Charakter gehabt und verhältnismäßig wenige Elemente umfasst haben, die außerdem die Form von in die Länge gezogenen Befestigungen (sog. Langwälle) hatten und eine sog. "landwere" bildeten. Die nächste in dem Artikel analysierte Frage ist das Problem des Typologiesierungscharakters der Bezeichnung "wildhaus." Unter Hinweis darauf, dass dieser Begriff im 14. Jahrhundert vor allem die Lage des durch ihn bezeichneten Befestigungsobjekts am Rande von Wildnissgebieten konnotierte, wird die weitgehende morphologische Heterogenität derjenigen Befestigungswerke an den östlichen Rändern des Preußenlandes aufgezeigt, die als "wildhaus" klassifiziert wurden oder klassifiziert werden konnten. Deshalb kann von "wildhaus" als morphologischem Typ eines befestigten Ortes keine Rede sein. Eine auf die Morphologie gestützte Typologie von Befestigungsobjekten kann nicht mit Typologien in Verbindung gebracht werden, die auf administrativen Kriterien beruhen oder sich auf Befestigungsbezeichnungen beziehen.

Die archäologische Erkundung des Wehrkomplexes von Bäslack zeigt trotz ihres sehr beschränkten Umfangs das große Erkenntnispotenzial, das in diesem Objekt liegt, und macht zugleich den höchst unbefriedigenden Wissensstand über die Funktion der kleineren und kleinen Befestigungswerke im spätmittelalterlichen Preußen deutlich. Weitere Untersuchungen auf diesem Forschungsgebiet gehören zweifellos zu einem der wichtigsten Postulate der regionalen preußischen Geschichtsforschung und der sie unterstützenden verschiedenen verwandten Fächer. 


\section{(WILD)HAUS IN BEZŁAWKI (BAYSELAUKEN, BÄSLACK) - REMARKS ON THE CONSTRUCTION OF FORTIFICATIONS OF THE TEUTONIC ORDER IN LATE MEDIEVAL PRUSSIA}

\section{Summary}

Key words: Late Middle Ages, late medieval Prussia, Warmia (Ermland), castles, construction of fortifications, the military affairs in the Late Middle Ages, conflicts

The article constitutes a collection of remarks concerning military aspects of the construction and functioning of the Teutonic Order's castle in Bäslack (Bayselauken, Bezławki) in the last decades of the $14^{\text {th }}$ century. Considerations included in the article refer to opinions expressed by the authors of the collective monograph about the late medieval settlement complex in Bezławki published in 2013. It presents the findings of archeological research in the castle and the village in the years 2008-2012.

Remarks presented in the article concern three out of six problems which are considered the most essential. While it goes beyond doubt that the castle played an important defensive role and fulfiled function as a getaway spot, the hypothesis of it being a "fortified camp" for the army troops during military actions of the Teutonic Order against the Lithuanians and Ruthenians has been undermined. It is not possible to consider it to play a military role on a strategic level, as do the authors of the monograph of 2013. In the second part of the article the author undermines the hypothesis about the "system" character of the complexes of fortifications situated on the eastern outskirts of Prussia. If the castle in Baslack was indeed part of some defensive system, this could operate only on the local level and consist of an insignificant number of elements including longitudinal fortifications constituting the so called "landwere." The next issue addressed by the author was a problem of the typological character of the term "wildhaus." As in the $14^{\text {th }}$ century the term connoted the location of the fortification on the edges of the Wildniss-areas, the author shows a far-reaching morphological diversity of fortifications on the eastern outskirts of Prussia, which were or could be classified as "wildhaus." Thus, a "wildhaus" cannot be classified as a morphological type of a fortification. The typology of fortifications based on the morphological criteria cannot be connected with the typology based on the administrative and terminological criteria.

Archeological examination of the Baslack fortification complex evinces its major cognitive potential and makes us aware of how little is known about the functioning of minor fortifications in late medieval Prussia. Further research in this research field belongs to one of the most important elements of historical science in the Prussian regional dimension and related humanities. 